Article

\title{
Tablet of Ximenia Americana L. Developed from Mucoadhesive Polymers for Future Use in Oral Treatment of Fungal Infections
}

\author{
Lucas Almeida ${ }^{1}$, João Augusto Oshiro Júnior ${ }^{1, * \mathbb{C}}$, Milena Silva ${ }^{1}$, Fernanda Nóbrega ${ }^{1}$, \\ Jéssica Andrade ${ }^{1}$, Widson Santos ${ }^{1}$, Angélica Ribeiro ${ }^{1}$, Marta Conceição ${ }^{2}$, Germano Veras ${ }^{3}$ (B) \\ and Ana Cláudia Medeiros ${ }^{1, *}$ \\ 1 Laboratório de Desenvolvimento e Ensaios de Medicamentos, Centro de Ciências Biológicas e da Saúde, \\ Universidade Estadual da Paraíba, R. Baraúnas, 351, Cidade Universitária, 58429-500, Campina Grande, \\ Paraíba, Brasil; lucasdealmeida2112@gmail.com (L.A.); nogueiracmilena@gmail.com (M.S.); \\ fernandapontesn@gmail.com (F.N.); jessicafarmacia2017@gmail.com (J.A.); \\ widsonmichael@gmail.com (W.S.); angelyca.p07@hotmail.com (A.R.) \\ 2 Centro de Tecnologia e Desenvolvimento Regional, Universidade Federal da Paraíba, Av. dos Escoteiros, \\ s/n, Mangabeira VII, 58055-000, João Pessoa, Paraíba, Brasil; martamaria8@yahoo.com.br \\ 3 Laboratório de Química Analítica e Quimiometria, Centro de Ciências Biológicas e da Saúde, \\ Universidade Estadual da Paraíba, R. Baraúnas, 351, Cidade Universitária, 58429-500, Campina Grande, \\ Paraíba, Brasil; germano@uepb.edu.br \\ * Correspondence: joaooshiro@yahoo.com.br (J.A.O.J.) anaclaudia@uepb.edu.br (A.C.M.); \\ Tel.: +55-83-3315-3300 (Ext. 3516) (A.C.M.)
}

Received: 28 December 2018; Accepted: 17 February 2019; Published: 20 February 2019

\begin{abstract}
The use of biocompatible polymers such as Hydroxypropylmethylcellulose (HPMC), Hydroxyethylcellulose (HEC), Carboxymethylcellulose (CMC), and Carbopol in solid formulations results in mucoadhesive systems capable of promoting the prolonged and localized release of Active Pharmaceutical Ingredients (APIs). This strategy represents a technological innovation that can be applied to improving the treatment of oral infections, such as oral candidiasis. Therefore, the aim of this study was to develop a tablet of Ximenia americana $\mathrm{L}$. from mucoadhesive polymers for use in the treatment of oral candidiasis. An X. americana extract (MIC of $125 \mu \mathrm{g} \cdot \mathrm{mL}^{-1}$ ) was obtained by turbolysis at $50 \%$ of ethanol, a level that demonstrated activity against Candida albicans. Differential Thermal Analysis and Fourier Transform Infrared Spectroscopy techniques allowed the choice of HPMC as a mucoadhesive agent, besides polyvinylpyrrolidone, magnesium stearate, and mannitol to integrate the formulation of $X$. americana. These excipients were granulated with an ethanolic solution $70 \% v / v$ at PVP $5 \%$, and a mucoadhesive tablet was obtained by compression. Finally, mucoadhesive strength was evaluated, and the results demonstrated good mucoadhesive forces in mucin disk and pig buccal mucosa. Therefore, the study allowed a new alternative to be developed for the treatment of buccal candidiasis, one which overcomes the inconveniences of common treatments, costs little, and facilitates patients' adhesion.
\end{abstract}

Keywords: Ximenia americana L.; compatibility; hydrophilic polymers; mucoadhesive tablets

\section{Introduction}

Oral candidiasis is a fungal infection that affects the superficial epithelium of the oral mucosa, most often caused by a disordered growth of Candida. Even though it is not a lethal disease, oral candidiasis should be avoided to prevent the invasion of other tissues and a subsequent development of systemic infection. Although infrequent, disseminated candidiasis has a mortality rate of $47 \%[1,2]$. 
Treatment of oral candidiasis can be topical or oral and commonly involves representatives of the azole class, such as fluconazole and ketoconazole. However, these drugs have disadvantages, such as hepatic side effects, a relatively high disease recurrence rate, and fungal resistance. Compared to synthetic antimicrobial drugs, medicinal plants have the advantages of not causing serious side effects and of not causing microbial resistance to treatment. Studies also show the modulating effect of plant extracts on the microbial resistance of synthetic Pharmaceutical Active Ingredients (APIs) against multi-resistant strains. The use of plants for therapeutic purposes is a popular practice supported by the World Health Organization (WHO), and it should be seen as an alternative in combatting oral candidiasis [3-5].

For this reason, research has investigated the pharmacological activities of plant species, particularly Ximenia americana. In folk medicine, X. americana leaves are used to treat infections in wounds and promote healing effects; its bark tea is used to combat hepatitis and malaria. The bark decoction is used as an antiseptic and a cicatrizant in wounds and snake bites. Due to its antiseptic activity, the seed oil is commonly applied cosmetically, in addition to having a high nutritional value. Several studies have already indicated the antimicrobial, anti-inflammatory, hepatoprotective, hypoglycemic, and antioxidant effects of X. americana [6-12].

Phytochemical investigations using aqueous, ethanolic, and hydroalcoholic extracts of $X$. americana demonstrate the presence of condensed tannins, hydrolysable tannins, saponins, polyphenols, and flavonoids, which are responsible for various biological activities [13-15]. Santana et al. (2018) characterized a hydroalcoholic extract of X. americana, and their results showed that it was possible to identify and quantify gallic acid as a chemical marker of X. americana. In addition, they developed $X$. americana tablets to combat antifungal and bacterial infections, highlighting the pharmacological potential of the species and its phytochemical components $[14,16]$.

Thus, given its wide geographical distribution and its biological potential, developing pharmaceutical formulations with X. americana is an innovative and promising proposal $[8,15,17,18]$. Within this context, the use of novel release forms as mucoadhesive tablets has resulted in a number of advantages over conventional formulations for treating oral infections, such as a longer residence time in the mucosa (saliva and mucosal movements remove conventional formulations quickly), increased permeability of the drug (against degrading agents present in the biological environment), and avoidance of the first-pass effect [19-21].

However, developing mucoadhesive tablets requires the choosing of suitable polymers to compose the formulation. The polymers must be capable of adhering to the mucous membranes of the human body, providing temporary retention at the action site, and increasing drug efficacy and adherence to treatment. In pharmaceutical forms, this property is widely used to develop polymeric release systems for oral, nasal, ocular, and vaginal use [22].

The hydrophilic and biocompatible polymers hydroxyethylcellulose (HEC), hydroxypropyl methylcellulose (HPMC), carboxymethylcellulose (CMC), and carbopol have an excellent mucoadhesive capacity. In addition, such polymers are characterized by a molecular matrix that increases the size of their pores according to their swelling ability, promoting a controlled release of the drug through diffusion [19,23-25].

Thus, the first step in developing any herbal pharmaceutical form requires detailed compatibility studies aimed at determining the most suitable adjuvants in order to compose the pharmaceutical formulation. These studies intend to characterize physical and chemical incompatibilities that may occur between drugs and pharmaceutical adjuvants, and they represent an important tool in producing a formulation with adequate stability and safety characteristics [26,27].

Therefore, this study aimed to evaluate the antifungal activity of X. Americana and to develop a mucoadhesive pharmaceutical form from a study of compatibility between the Plant Active Pharmaceutical Ingredient (PAPI) and pharmaceutical excipients for the treatment of oral candidiasis. 


\section{Materials and Methods}

\subsection{Materials}

Carbopol $\left(M_{\mathrm{W}}=940.00 \mathrm{~g} \cdot \mathrm{mol}^{-1}\right)$, colloidal silicon dioxide $\left(M_{\mathrm{W}}=60.08 \mathrm{~g} \cdot \mathrm{mol}^{-1}\right)$, magnesium stearate $\left(M_{\mathrm{W}}=591.24 \mathrm{~g} \cdot \mathrm{mol}^{-1}\right)$, and polyvinylpyrrolidone $\mathrm{K}-30\left(M_{\mathrm{w}}=50.00 \mathrm{~g} \cdot \mathrm{mol}^{-1}\right)$ were purchased from Henrifarma Produtos Químicos e Farmacêuticos Ltda. (Cambuci, Brazil). Aspartame $\left(M_{\mathrm{w}}=294.30 \mathrm{~g} \cdot \mathrm{mol}^{-1}\right)$ was purshased from Mapric Produtos Farmacocosméticos Ltda. (São Paulo, Brazil); sodium saccharin $\left(M_{\mathrm{w}}=205.16 \mathrm{~g} \cdot \mathrm{mol}^{-1}\right)$ from Via Farma-Distribuidora de medicamentos Ltda. (São Paulo, Brazil); fructose $\left(M_{\mathrm{W}}=180.16 \mathrm{~g} \cdot \mathrm{mol}^{-1}\right)$ from Rem Produtos Farmacêuticos Ltda. (Campina Grande, Brasil); sodium carboxymethylcellulose $\left(M_{\mathrm{w}}=262.19 \mathrm{~g} \cdot \mathrm{mol}^{-1}\right)$ from Pharmachemical Comércio e Produtos Farmacêuticos Ltda. (São Caetano do Sul, Brazil); hydroxyethylcellulose $\left(M_{\mathrm{W}}=806.94 \mathrm{~g} \cdot \mathrm{mol}^{-1}\right)$ from Apsen Farmaceutica S/A (São Paulo, Brazil); Hydroxypropylmethylcellulose $\left(M_{\mathrm{w}}=1261.45 \mathrm{~g} \mathrm{~mol}^{-1}\right)$ from Unna Derme Comércio de Produtos Farmacêuticos Ltda. (Campina Grande, Brazil); talc $\left(M_{\mathrm{w}}=379.26 \mathrm{~g} \cdot \mathrm{mol}^{-1}\right)$ from Sintética Distribuidora Química Farmacêutica Ltda. (Capivari, Brazil); mannitol $\left(M_{\mathrm{w}}=182.17 \mathrm{~g} \cdot \mathrm{mol}^{-1}\right)$ from Allchem Química Indústria e Coméricio Ltda. (Rio Grande, Brazil); and lactose monohydrate $\left(M_{\mathrm{W}}=360.31 \mathrm{~g} \cdot \mathrm{mol}^{-1}\right)$ from Galena Química e Farmacêutica Ltda. (Campinas, Brazil).

\subsection{Plant Material}

Barks of X. americana L. were collected from the semiarid region of Paraíba State, Brazil. Exsiccata was prepared and indentified at the Professor Jayme Coelho de Morais Herbarium, located at the Federal University of Paraíba (Areia city, Paraíba), under the voucher number EAN-100493. Raw barks were dried in an air-forced oven operating at $40^{\circ} \mathrm{C}$ and then powdered using a knife mill.

\subsection{Obtaining the X. Americana Extracts}

The extracts were prepared by three different extractive methods: turbolysis or turbo-extraction, maceration, and ultrasonic waves. Hydroethanolic solutions were prepared in varying proportions $(50: 50,30: 70$ and $10: 90, v / v)$ containing $20 \%(w / v)$ vegetable drug. In the turbolysis, the extract was subjected to high shear agitation using Ultra-turrax ${ }^{\circledR}$ apparatus (IKA, Campinas, Brazil) at $6000 \mathrm{rpm}$ for $15 \mathrm{~min}$ under an ice bath for temperature maintenance. The maceration was carried out in a static manner, without solvent renovation, conditioning the extractive solutions in amber glass for seven days under occasional stirring. Ultrasonic wave extraction was performed in an ultrasonic washer (Ultrasonic Cleaner-UNIQUE, Indaiatuba, Brazil) in a water bath at $40{ }^{\circ} \mathrm{C}$ for a period of 60 minutes.

All liquid extracts were filtered, concentrated under reduced pressure on a rotary evaporator, and then dried in an air oven at $40{ }^{\circ} \mathrm{C}$. The dried extracts were stored in hermetically sealed vials under refrigeration $\left( \pm 5^{\circ} \mathrm{C}\right)$ until further analysis.

\subsection{Evaluation of Antifungal Activity}

The antifungal activity was evaluated in vitro by the broth microdilution method, determining the Minimum Inhibitory Concentration (MIC) of each extract. Standard American Type Culture Collection (ATCC) strains of Candida albicans (18804) were used. The microbial suspension was standardized in a UV-VIS (UVmini-1240-Shimadzu, Kyoto, Japan) spectrophotometer at a wavelength of $530 \mathrm{~nm}$ to contain the equivalent of $10^{6} \mathrm{CFU} \mathrm{mL} \mathrm{m}^{-1}$. The extracts were solubilized in $10 \%$ DMSO. Nystatin was used as a positive control [28].

\subsection{Binary Mixtures}

Physical mixtures of the dry extract (AMX) and pharmaceutical excipients were prepared by geometric dilution in the proportion 1:1, 1:2, and 2:1 (AMX: excipient $w / w$ ). Functional categories of each selected excipient are shown in Appendix A (Table A1). The compatibility study was conducted 
by analyzing the binary mixtures by Differential Thermal Analysis (DTA) and Fourier Transform Infrared Spectroscopy (FTIR) [29].

\subsection{Thermal Analysis}

The DTA curves of AMX, binary mixtures, and pharmaceutical excipients were obtained on a simultaneous DTA/TGA DTG-60 (Shimadzu, Kyoto, Japan) thermal analyzer using an aluminum sample holder containing a $2 \pm 0.1 \mathrm{mg}$ sample under an atmosphere of nitrogen with a flow of $50 \mathrm{~mL} \cdot \mathrm{min}^{-1}$. The samples were subjected to heating in a temperature range of 25 to $400{ }^{\circ} \mathrm{C}$ in programming of $10^{\circ} \mathrm{C} \cdot \mathrm{min}^{-1}$. For calibration of the equipment, Indium (melting point $156.6^{\circ} \mathrm{C}$ ) was used as the standard.

Thermogravimetry (TG) was only used for the characterization of the extract. Thus, the thermogravimetric curve of the AMX was obtained from a simultaneous thermal analyzer previously mentioned for DTA analysis, using an alumina sample holder containing $8.0 \pm 0.5 \mathrm{mg}$ of sample, under nitrogen atmosphere at a flow rate of $50.0 \mathrm{~mL} \cdot \mathrm{min}^{-1}$ as the purge gas. The sample was conditioned at a temperature range of $25-900{ }^{\circ} \mathrm{C}$ at a heating rate of $10{ }^{\circ} \mathrm{C} \cdot \mathrm{min}^{-1}$. The data were analyzed using the TA60-WS software (Shimadzu, Kyoto, Japan).

\subsection{FTIR}

Absorption spectra in the infrared region were obtained from the Shimadzu Spectrophotometer, IRPrestige model (Shimadzu, Kyoto, Japan), using KBr pellets, at the range of $4000-400 \mathrm{~cm}^{-1}$. Data were analyzed using Origin ${ }^{\circledR}$ software, version 8.0 (OriginLab Corporation, Northampton, MA, USA).

\subsection{Formulation Development}

From the compatibility study performed by DTA and FTIR, the pharmaceutical excipients that were compatible with the AMX plant extract were selected to form the formulation. Based on the chosen excipients, different formulations were proposed, following the concentration limits recommended for each component [29]. The proposed formulations were then monitored for their compressibility and flow properties, and the best performance formulation was chosen for tableting through direct compression, using a Lemaq Monopress LM-1 compressor (Lemaq, Diadema, Brazil) [30-32].

\subsection{Mucoadhesion}

The mucoadhesive strength of the formulation was analyzed using a TAXT plus texture analyzer (Stable Micro Systems ${ }^{\circledR}$, Surrey, UK). Mucin disks or pig buccal mucosa were used for mucoadhesion analysis. Initially, the mucin disc was prepared by compressing raw swine mucin $(250 \mathrm{mg})$ moistened with $50 \mu \mathrm{L}$ of $8 \%(w / w)$ mucin dispersion and using a tablet compressor with a diameter of $123 \mathrm{~mm}$, and the pig buccal mucosa was obtained from a local slaughterhouse. First, $50 \mu \mathrm{L}$ of artificial saliva was applied to the surface of the mucin disk before the experiment and the mucosa was immersed in human saliva to simulate the buccal environment for $30 \mathrm{~s}$. Then, the mucin disks or pig buccal mucosa were taped horizontally in a cylindrical probe of the texturometer with double-sided tape to keep them static. After that, the tablet was adhered to the surface of the lower acrylic plate and was placed below the cylindrical probe, thereby triggering the lowering of the cylindrical test at a rate of $1 \mathrm{~mm} / \mathrm{sec}$ until the mucin disc reached the tablet. The cylindrical probe was kept in contact with no force applied for $60 \mathrm{~s}$ to ensure intimate contact between the tablet and the mucin disc. After this time, the test was ended at a speed of $1 \mathrm{~mm} / \mathrm{sec}[33,34]$. During the experiment, a force-time curve was recorded through the Expert Texture Exponent 32 software (version, Stable Micro Systems, Surrey, UK) and the area under the force-distance curve during the withdrawing phase and peak adhesion was calculated as the work of adhesion (Wad). This process was replicated five times at $37 \pm 1^{\circ} \mathrm{C}$. 


\section{Results and Discussion}

\subsection{Evaluation of Antifungal Activity}

The results obtained for determining the antifungal activity of the X. americana rotavapor extracts are described in Table 1.

Table 1. Minimum Inhibitory Concentration (MIC) of extracts of X. Americana.

\begin{tabular}{ccccc}
\hline & & \multicolumn{3}{c}{ MIC $\left(\mu \mathrm{g} \cdot \mathrm{mL}^{-\mathbf{1}}\right)$} \\
\cline { 2 - 5 } & EtOH (\%) & Maceration & Turbolysis & Ultrasound \\
\hline \multirow{3}{*}{ X. americana } & 50 & 250.00 & 125.00 & 125.00 \\
& 70 & 125.00 & 125.00 & 250.00 \\
& 90 & 125.00 & 250.00 & 250.00 \\
\hline
\end{tabular}

The extracts evaluated in this study showed inhibitory activity in a concentration range between 125 and $250 \mu \mathrm{g} \cdot \mathrm{mL}^{-1}$. The MIC of $125 \mu \mathrm{g} \cdot \mathrm{mL}^{-1}$ was presented by extracts of $70 \%$ and $90 \%$ ethanol for maceration, $50 \%$ and $70 \%$ for turbolysis, and $50 \%$ for ultrasound. Previous research has demonstrated the antifungal activity of a chloroform extract of $X$. americana against $C$. albicans, as well as the absence of activity from methanolic and aqueous extracts; we also found another study that reported weak activity of the methanolic and aqueous extracts of the stem bark [35,36].

In contrast, a study comparing the action of 31 plant species against $C$. albicans showed that only six inhibited it, and the methanolic extract of $X$. americana showed one of the lowest $\mathrm{IC}_{50}$ values obtained in the study $\left(8.12 \mu \mathrm{g} \cdot \mathrm{mL}^{-1}\right)$. Previous studies also reported the activity of other species of the genus Ximenia against $C$. albicans, indicating the potential of these species in the treatment of oral candidiasis, which had already been reported in ethnopharmacological studies [37-39].

Studies suggest that most of the secondary metabolites present in plant species have antifungal activities, and the synergism of the actions of these compounds is an effective alternative in treating fungal infections. Previous research has suggested that phytocomposites can inhibit fungal cell wall formation and cause cell membrane rupture, fungal mitochondria dysfunction, inhibition of cell division, inhibition of RNA/DNA and/or protein synthesis, and inhibition of efflux pumps [40-42].

With the similar values of MIC in mind, we chose the AMX extract obtained by turbolysis at $50 \%$ of EtOH to perform the PAPI-excipient compatibility study because it is a cheaper, faster method and an extractive solution with lower alcohol. The use of ethanol as a solvent is a strategy that follows green chemistry principles, since it is more appropriate biologically and environmentally [33].

\subsection{Thermal Characterization of AMX}

The DTA curve of AMX (Figure 1a) shows the presence of an endothermic peak around $98.67^{\circ} \mathrm{C}$ $\left(\Delta H=283.69 \mathrm{~J} \cdot \mathrm{g}^{-1}\right)$, certainly related to the loss of volatile compounds, ethanol, and water in the sample. This event at the TG curve (Figure $1 b$ ) is related to a mass loss of $9.56 \%$ of the sample. At the TG curve, in reference to the decomposition of organic compounds, a loss of mass equivalent to $51.94 \%$ was observed starting at $211^{\circ} \mathrm{C}$. The residue that formed at the end of the heating corresponded to $38.5 \%$ of the total mass analyzed. 

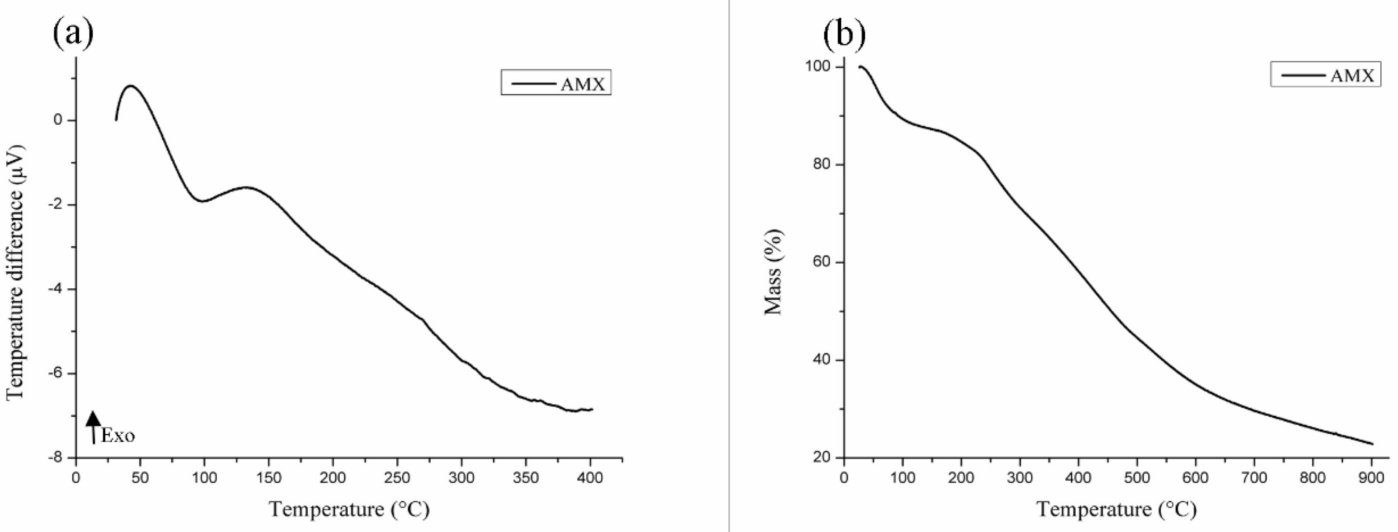

Figure 1. DTA (a) and TG (b) curves of AMX.

\subsection{Compatibility Study}

\subsubsection{DTA}

Thermoanalytic techniques, such as DTA, are widely used to detect incompatibilities in a short period of time, with the curve of the mixture being a result of the individual curves of each substance analyzed. The suppression, disappearance, appearance, or displacement of thermal events, as well as variation in the expected values of enthalpy, should be considered as possible incompatibility. These parameters were used to evaluate the binary mixtures described below [43].

The DTA curves of the binary mixtures of the AMX plant extract and the pharmaceutical excipients are shown in Figures 2-4, and the data are described in Appendix A (Table A2). Most of the mixtures showed significant variations of their thermal profiles. The aspartame thermoanalytical curves (Figure 2a) recorded a shift of the melting temperature of the pharmaceutical excipient $\left(249.17^{\circ} \mathrm{C}\right)$ at all mixing ratios-1:1 $\left(235.55{ }^{\circ} \mathrm{C}\right), 1: 2\left(237.58{ }^{\circ} \mathrm{C}\right)$, and 2:1 $\left(234.78{ }^{\circ} \mathrm{C}\right)$ - suggestive of physical incompatibility. Variations of the energy involved in these thermal events were also observed and predicted according to the proportion of the mixture [29].

Signs of AMX-pharmaceutical excipient incompatibility were observed with carbopol (Figure 2b), in the curves of which a drastic reduction of the energy involved in the stages of the decomposition of CBP was observed, leading to the disappearance of these peaks. This can be considered as a physical incompatibility, despite the presence of AMX characteristics in the thermal profiles of the mixtures [44].

The thermal curves of the mixtures with the carboxymethylcellulose (Figure 2c) and the colloidal silicon dioxide (Figure 2d) demonstrated the preservation of the characteristics of both AMX and the pharmaceutical excipients, thus indicating no apparent physical incompatibility between them. 

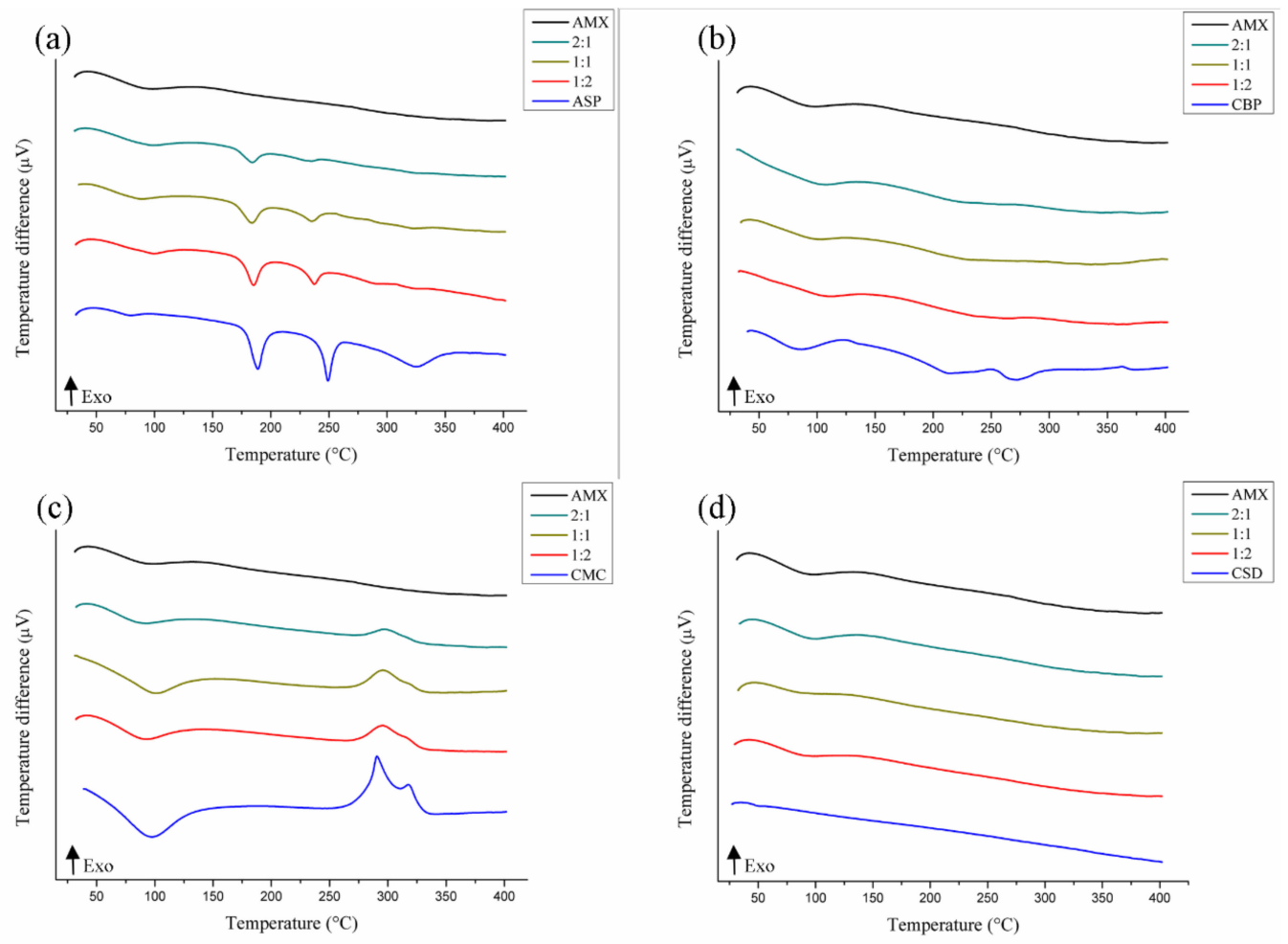

Figure 2. DTA curves of binary mixtures of AMX with pharmaceutical excipients: aspartame (a), carbopol (b), carboxymethylcellulose (c), and colloidal silicon dioxide (d).

According to Figure 3, physical incompatibility was also possible in the AMX-fructose mixtures (Figure 3a). It shows displacement of melting temperatures $\left(107.92{ }^{\circ} \mathrm{C}\right)$ and decomposition $\left(210.13 / 279.24{ }^{\circ} \mathrm{C}\right)$ of the FRU at the ratio $1: 1\left(126.09 / 195.05 / 222.28^{\circ} \mathrm{C}\right)$, anticipation of thermal events at $1: 2\left(101.92 / 149.76 / 237.24^{\circ} \mathrm{C}\right)$, and the junction of all events at $2: 1$, resulting in a single high-intensity endothermic peak $\left(\Delta H=-294.63 \mathrm{~J} \cdot \mathrm{g}^{-1}\right)$ at $121.37^{\circ} \mathrm{C}[29]$.

For the AMX-hydroxyethylcellulose mixture (Figure 3b), suppression of the second HEC decomposition event $\left(364.60^{\circ} \mathrm{C} / \Delta H=10.15 \mathrm{~J} \cdot \mathrm{g}^{-1}\right)$ was observed at $1: 1$ and $1: 2$, and a temperature delay of this event was seen at 2:1 $\left(383.22^{\circ} \mathrm{C}\right)$ with suppression of the first HEC decomposition event $\left(343.28{ }^{\circ} \mathrm{C}\right)$, suggesting possible incompatibility, despite the presence of thermal characteristics of the AMX in the mixtures. These characteristics were also represented in the binary mixtures with hydroxypropyl methylcellulose (Figure 3c), in which no apparent alterations were observed in the thermal profiles that characterize incompatibility with the AMX.

Analyzing the AMX-lactose curves (Figure 3d), we were able to verify some evidence of physical incompatibility. Thermal analysis of the 1:1 ratio mixture showed a change in the temperature and melting energy of the LAC in the mixture, from $219.34^{\circ} \mathrm{C}\left(\Delta H=-226.34 \mathrm{~J} \cdot \mathrm{g}^{-1}\right)$ to $207.32^{\circ} \mathrm{C}$ $\left(\Delta H=-4.14 \mathrm{~J} \cdot \mathrm{g}^{-1}\right)$, as well as the disappearance of the second decomposition event of this excipient $\left(304.85^{\circ} \mathrm{C} / \Delta H=-137.36 \mathrm{~J} \cdot \mathrm{g}^{-1}\right)$ [29]. Displacement at this temperature was also found in ratios 1:2 $\left(211.31{ }^{\circ} \mathrm{C}\right)$ and $2: 1\left(210.83{ }^{\circ} \mathrm{C}\right)$, in addition to the suppression of decomposition events of the pharmaceutical excipient $\left(241.72 / 304.85^{\circ} \mathrm{C}\right)$. 

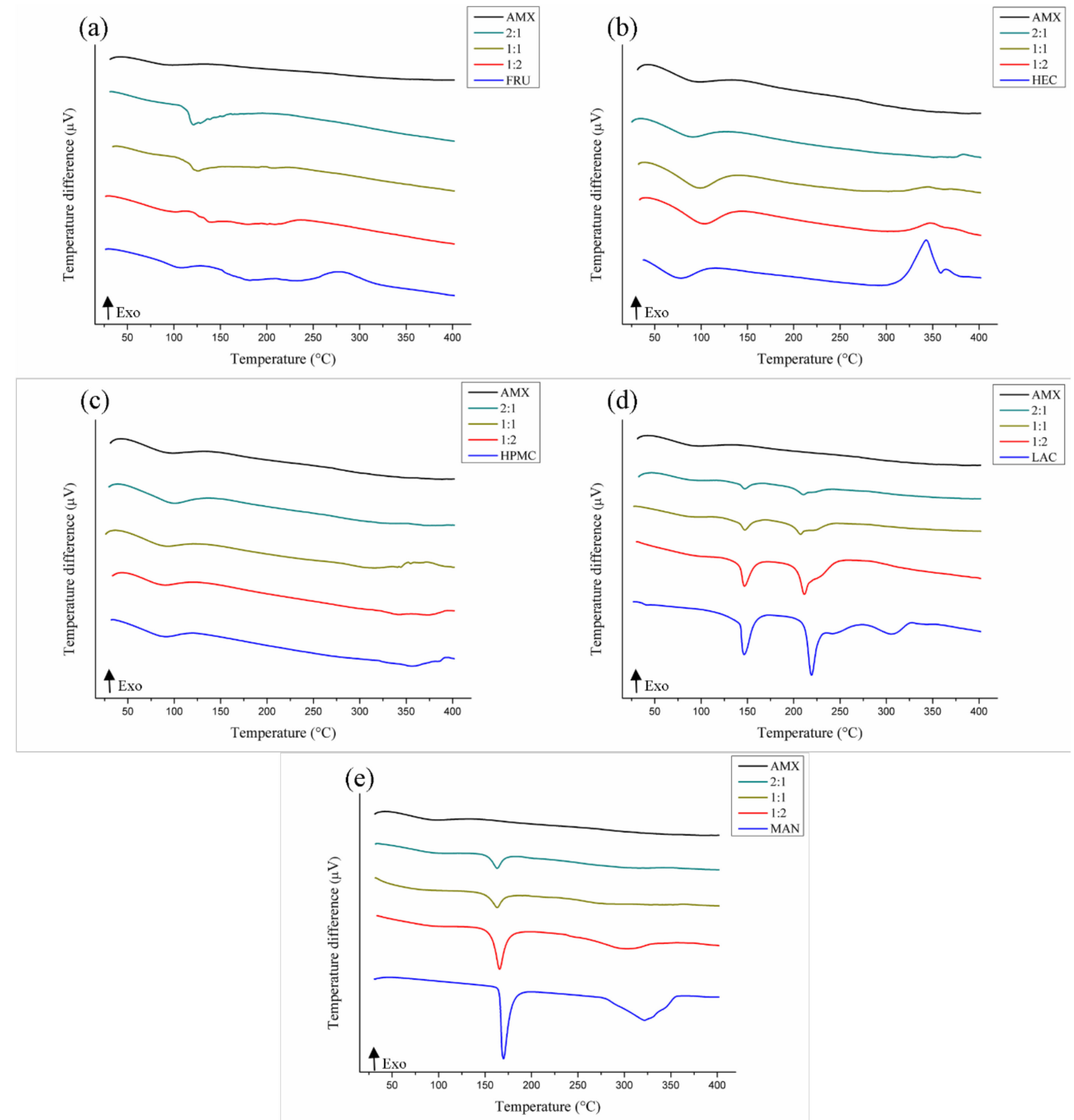

Figure 3. DTA curves of binary mixtures of AMX and pharmaceutical excipients: fructose (a), hydroxyethylcellulose (b), hydroxypropyl methylcellulose (c), lactose (d), and mannitol (e).

Two endothermic events characterized the thermal profile of mannitol (Figure 3e): melting $\left(169.89^{\circ} \mathrm{C} / \Delta H=-450.53 \mathrm{~J} \cdot \mathrm{g}^{-1}\right)$ and decomposition $\left(321.83^{\circ} \mathrm{C} / \Delta H=-812.74 \mathrm{~J} \cdot \mathrm{g}^{-1}\right)$. The melting point found is close to the one described in the literature, at $166-168^{\circ} \mathrm{C}$ [45]. Signals of AMX-MAN incompatibility were verified in the binary mixtures, with displacement of these events at $1: 2$ $\left(165.63 / 304.15^{\circ} \mathrm{C}\right)$ and $2: 1\left(162.94 / 325.73^{\circ} \mathrm{C}\right)$. At the 1:1 ratio, the anticipated melting temperature was observed, along with a drastic energy decrease $\left(163.10^{\circ} \mathrm{C} / \Delta H=-50.80 \mathrm{~J} \cdot \mathrm{g}^{-1}\right)$ and the disappearance of the peak decomposition of the pharmaceutical excipient $\left(321.83^{\circ} \mathrm{C}\right)$.

For magnesium stearate (Figure 4a), the endothermic AMX moisture loss peaks $\left(98.67^{\circ} \mathrm{C} / \Delta H=\right.$ $\left.-283.69 \mathrm{~J} \cdot \mathrm{g}^{-1}\right)$ and melting point $\left(129.00^{\circ} \mathrm{C} / \Delta H=255.25 \mathrm{~J} \mathrm{~g}^{-1}\right)$ melted, resulting in a single low energy peak in the 1:1 ratio $\operatorname{mix}\left(127.00^{\circ} \mathrm{C} / \Delta H=-71.44 \mathrm{~J} \mathrm{~g}^{-1}\right)$. Commercial samples of magnesium stearate have a melting range of $117-150{ }^{\circ} \mathrm{C}$ [29]. Still in the ratio 1:1, the magnesium stearate decomposition event $\left(319.75{ }^{\circ} \mathrm{C} / \Delta H=-379.99 \mathrm{~J} \cdot \mathrm{g}^{-1}\right)$ was seen to be suppressed. In addition, displacement of this temperature was observed at the $1: 2$ mixture $\left(341.03{ }^{\circ} \mathrm{C} / \Delta H=-204.32 \mathrm{~J} \cdot \mathrm{g}^{-1}\right)$, indicating physical incompatibility in the AMX-MST mix.

In the literature, a possible explanation put forth for incompatibility with magnesium stearate is its chemical nature, a mixture of organic salts formed by magnesium cations and anions from different 
fatty acids that can generate chemical reactions with the active compounds by forming new products of degradation [46].

Saccharin also showed evidence of physical incompatibility with AMX (Figure 4c). Saccharin salts have a melting temperature above $300^{\circ} \mathrm{C}$; the melting temperatures determined in the mixtures still remained close to that of the excipient $\left(365.15^{\circ} \mathrm{C} / \Delta H=-210 \mathrm{~J} \cdot \mathrm{g}^{-1}\right)$, but the energy spent in these thermal events was significantly reduced at $1: 1\left(356.32{ }^{\circ} \mathrm{C} / \Delta H=-26.91 \mathrm{~J} \cdot \mathrm{g}^{-1}\right), 1: 2\left(357.94{ }^{\circ} \mathrm{C} / \Delta H=-65.39 \mathrm{~J} \cdot \mathrm{g}^{-1}\right)$, and 2:1 $\left(356.49^{\circ} \mathrm{C} / \Delta H=-18.02 \mathrm{~J} \cdot \mathrm{g}^{-1}\right)[47]$.

Polyvinylpyrrolidone K-30 (Figure 4b) and talc (Figure 4d) maintained their thermal characteristics in a mixture with AMX, demonstrating that no changes occurred that were not predicted.
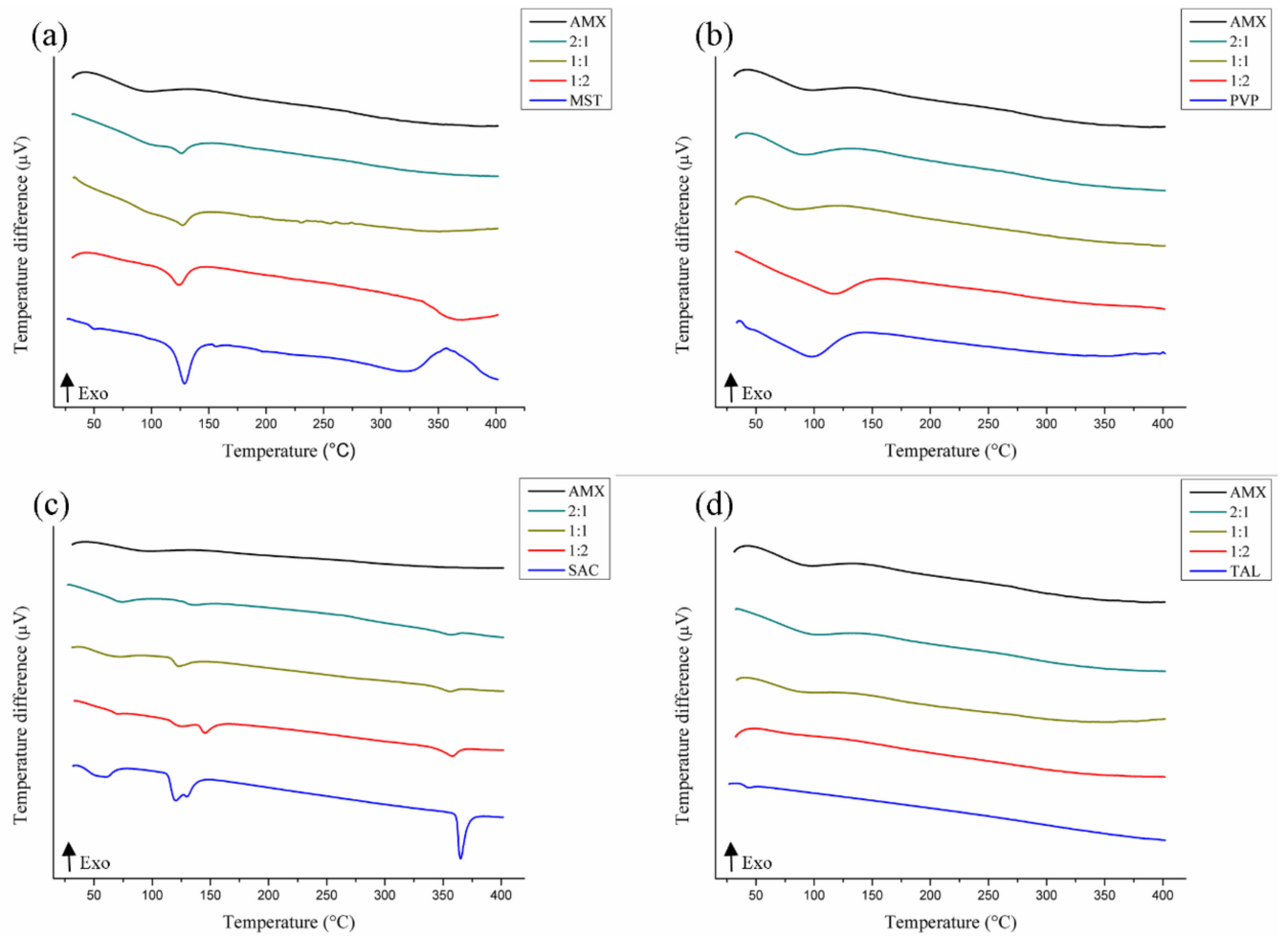

Figure 4. DTA curves of the binary mixtures of AMX and pharmaceutical excipients: magnesium stearate (a), polyvinylpyrrolidone K-30 (b), sodium saccharin (c), and talc (d).

In summary, according to the results of this study, CSD, HPMC, CMC, PVP, and TAL were the pharmaceutical excipients that showed no evidence of physical incompatibility with the AMX. The binary mixtures were then submitted to FTIR for confirmation of possible incompatibilities.

PAPI-excipient compatibility studies are important tools that predict possible reactions between the formulation components that may occur during the storage period under storage conditions. The combination of thermal techniques (such as DTA) and non-thermal techniques (such as FTIR) is successful in identifying and confirming incompatibilities. Since these techniques present different work fundamentals and vary the analysis time, amount of sample, and mechanical and/or thermal stress employed, the results obtained are complementary and provide different conclusions. However, in the absence of evidence of interaction, compatibility should be confirmed by FTIR [43,48].

\subsubsection{FTIR}

The FTIR spectra of the AMX extract and their binary mixtures are set forth in Figures 5-7. According to the FTIR spectrum obtained from the AMX (Figure 5), a wide and intense absorption band is visible between 3800 and $3000 \mathrm{~cm}^{-1}$, suggestive of $\mathrm{O}-\mathrm{H}$ stretching. These hydroxyls may be related to the phenolic compounds and moisture content present in the extract, since it is an amorphous and 
hygroscopic sample. In addition, the presence of organic compounds in the extract was characterized in the spectrum by the occurrence of a low-intensity peak in the range between 3000 and $2850 \mathrm{~cm}^{-1}$, indicative of $\mathrm{C}-\mathrm{H}$ stretching. Acute peaks observed between 1600 and $1475 \mathrm{~cm}^{-1}$ are possibly related to $\mathrm{C}=\mathrm{C}$ bonds of aromatics. Near this region, characteristic peaks of $\mathrm{C}-\mathrm{H}$ were observed for folding between 1450 and $1375 \mathrm{~cm}^{-1}$, as well as peaks suggestive of $\mathrm{C}-\mathrm{O}$ stretching in the range of 1300 to $1000 \mathrm{~cm}^{-1}$. Between 788 and $674 \mathrm{~cm}^{-1}$, narrow peaks of a low intensity were visualized, probably related to $\mathrm{C}-\mathrm{H}$ bonds in substituted aromatics. These chemical bonds refer to a variety of functional groups-such as ethers, esters, and carboxylic acids-that accompany the chemical composition of flavonoids, tannins, anthraquinones, and other secondary metabolites present in the extract [16].

Indices of AMX-pharmaceutical excipient chemical incompatibility were evaluated, taking into account the emergence of new bands, as well as changes in the absorption ranges and/or intensity of the characteristic peaks of the extract and excipient in the binary mixtures $[27,46]$.
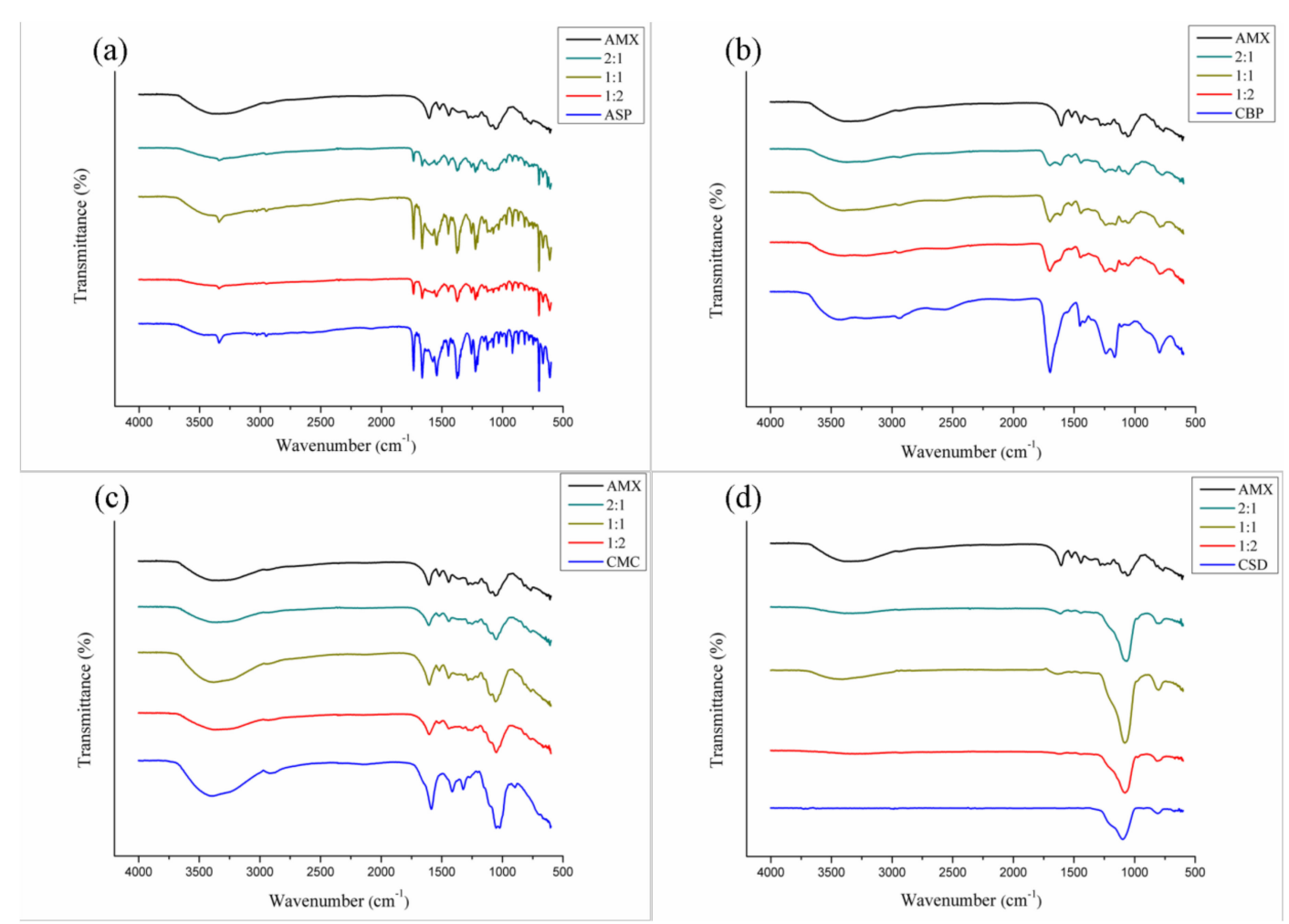

Figure 5. FTIR spectra for AMX and mixtures thereof with pharmaceutical excipients: aspartame (a), carbopol (b), carboxymethylcellulose (c), and colloidal silicon dioxide (d).

The spectra of the binary mixtures of AMX with aspartame (Figure 5a) did not show any apparent changes in the spectroscopic profile of the plant extract; however, the characteristic peaks of the pharmaceutical excipient were predominantly observed in all the analyzed spectra, even at a ratio with a higher proportion of the extract $(2: 1)$. The peaks related to the AMX were not very pronounced throughout the spectra, due to the overlap of absorption bands of the pharmaceutical ingredient. The overlapping bands are not considered a parameter that is indicative of chemical incompatibility [49]. The decrease in peak intensity, observed in the 1:2 and 2:1 mixtures, may be attributed to possible changes in the geometric mixture of the components, since this reduction occurred on the spectrum as a whole. Therefore, there was no evidence of chemical incompatibility between AMX and ASP.

With respect to the mixtures of AMX and carbopol (Figure 5b), representative absorption bands of the plant extract could be visualized in all mixing proportions, with overlapping rare peaks. As expected, the intensity of the bands was also found to vary between the mixtures, according to 
the proportion. The same behavior was observed in mixtures of AMX and carboxymethylcellulose (Figure 5c). Therefore, it is clear that no evidence shows that AMX interacted chemically with these pharmaceutical excipients.

The binary mixtures of AMX-colloidal silicon dioxide (Figure 5d) showed spectra consistent with the characteristics of each of the components of the mixture. However, the intensity of the peaks related to the extract was reduced. This can be explained by the presence of a broad and intense band at $1080 \mathrm{~cm}^{-1}$, suggestive of $\mathrm{Si}-\mathrm{O}-\mathrm{Si}$ bonding of the siloxane groups of the pharmaceutical ingredient, which promotes overlapping and attenuation of the other spectral bands. A chemical compatibility can be seen between AMX and CSD.

Indices of chemical compatibility were also determined in spectra of the AMX mixtures with fructose (Figure 6a), hydroxyethylcellulose (Figure 6b), hydroxypropyl methylcellulose (Figure 6c), lactose (Figure 6d), and mannitol (Figure 6e). The obtained spectra resulted from a sum of characteristics of the extract and the pharmaceutical ingredient evaluated.

For mixtures with FRU (Figure 6a), the intensity of the AMX peaks was shown to be positively influenced by a greater amount of extract in the mixture (2:1), as predicted. In a similar way, the excipient at 1:2 was verified, in which the intensity of the peaks related to FRU increases. In mixtures with HEC (Figure $6 \mathrm{~b}$ ), a different behavior was noted. The total peaks resulting from the mixture are reproducible between the different proportions, and their intensities increase (compared to 1:1 mixture) when the amount of the extract (2:1) or the excipient (1:2) is increased; in other words, 1:2 and 2:1 present similar bands of intensity, showing that both the AMX and the pharmaceutical excipient have an equal influence on the spectrum of the mixture.

The spectra of the AMX-hydroxypropylmethylcellulose mixture (Figure 6c) expressed opposite-than-expected effects with the increasing proportions of extract and excipient in the binary mixtures: the 1:1 proportion mixture had higher peak intensities than those from mixtures with higher amounts of excipient (1:2) and extract (2:1). Band fusion may have occurred at the regions of absorption common to the components of the 1:1 mixture, which could not be seen at the other proportions. 

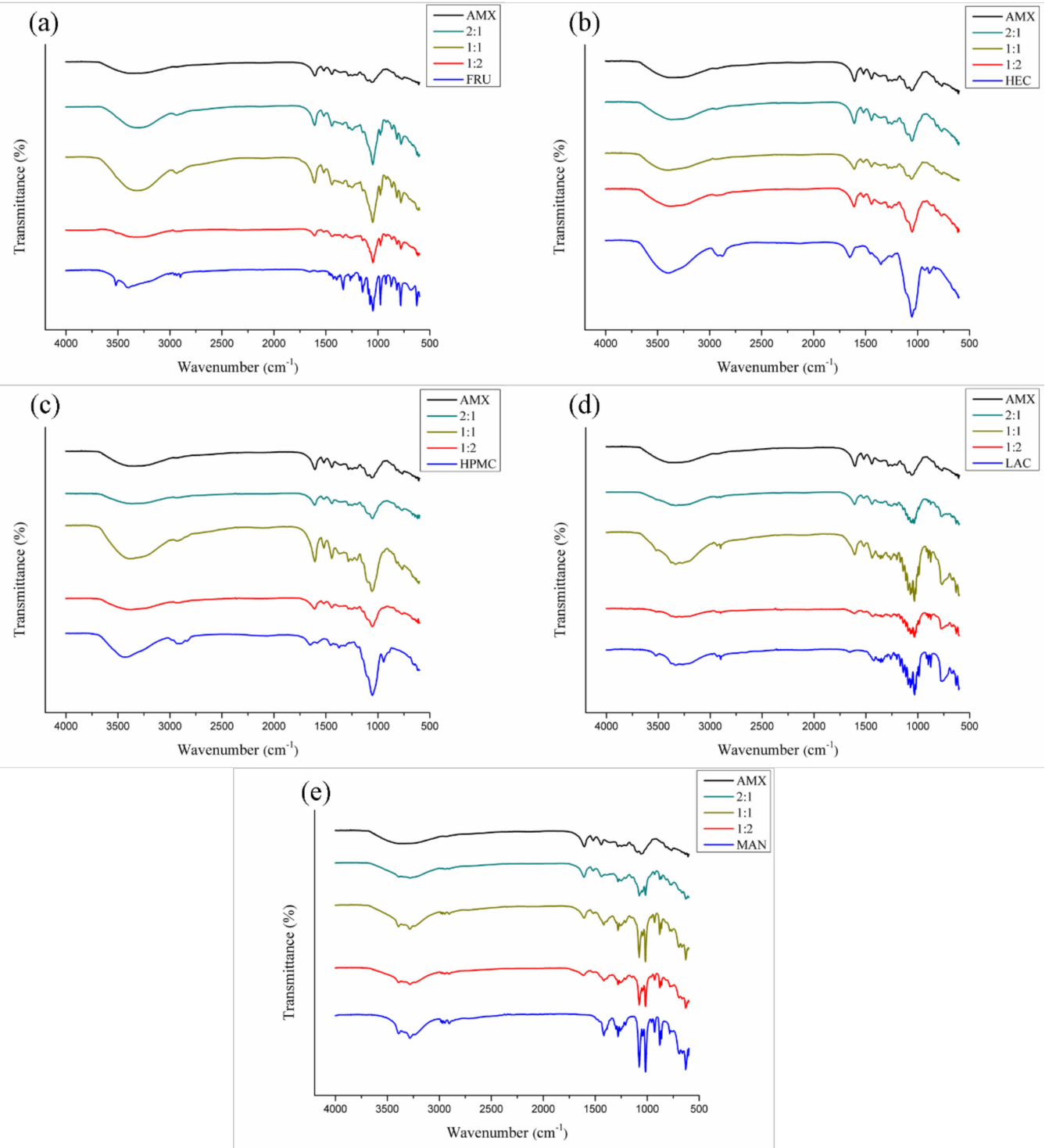

Figure 6. FTIR spectra for binary mixtures of AMX and pharmaceutical excipients: fructose (a), hydroxyethylcellulose (b) and hydroxypropylmethylcellulose (c), lactose (d), and mannitol (e).

A similar profile to that observed in the HPMC mixture was repeated for lactose (Figure $6 \mathrm{~d}$ ), mannitol (Figure 6e), polyvinylpyrrolidone K-30 (Figure 7b), saccharin (Figure 7c), and talc (Figure 7d) in mixtures with AMX. Generally, the spectra retained the identity of the AMX, as well as those of the pharmaceutical excipients; no displacement of the characteristic absorption regions of the mixtures' components was observed. Some bands related to the extract were superimposed because the region of spectral absorption was with the same as that for the excipients; however, the intensity of the absorption bands was verified between the mixtures within what was expected or could be explained. Thus, no evidence was shown for chemical incompatibility between these pharmaceutical excipients and AMX.

For mixtures with magnesium stearate (Figure 7a), the intensity of the AMX and excipient peaks were shown to be directly related to the component concentration in the mixtures: AMX characteristic absorption bands were most evident at the 2:1 proportion mixture, and characteristic peaks of the MST were more intense at the 1:2 proportion mixture, as expected. 

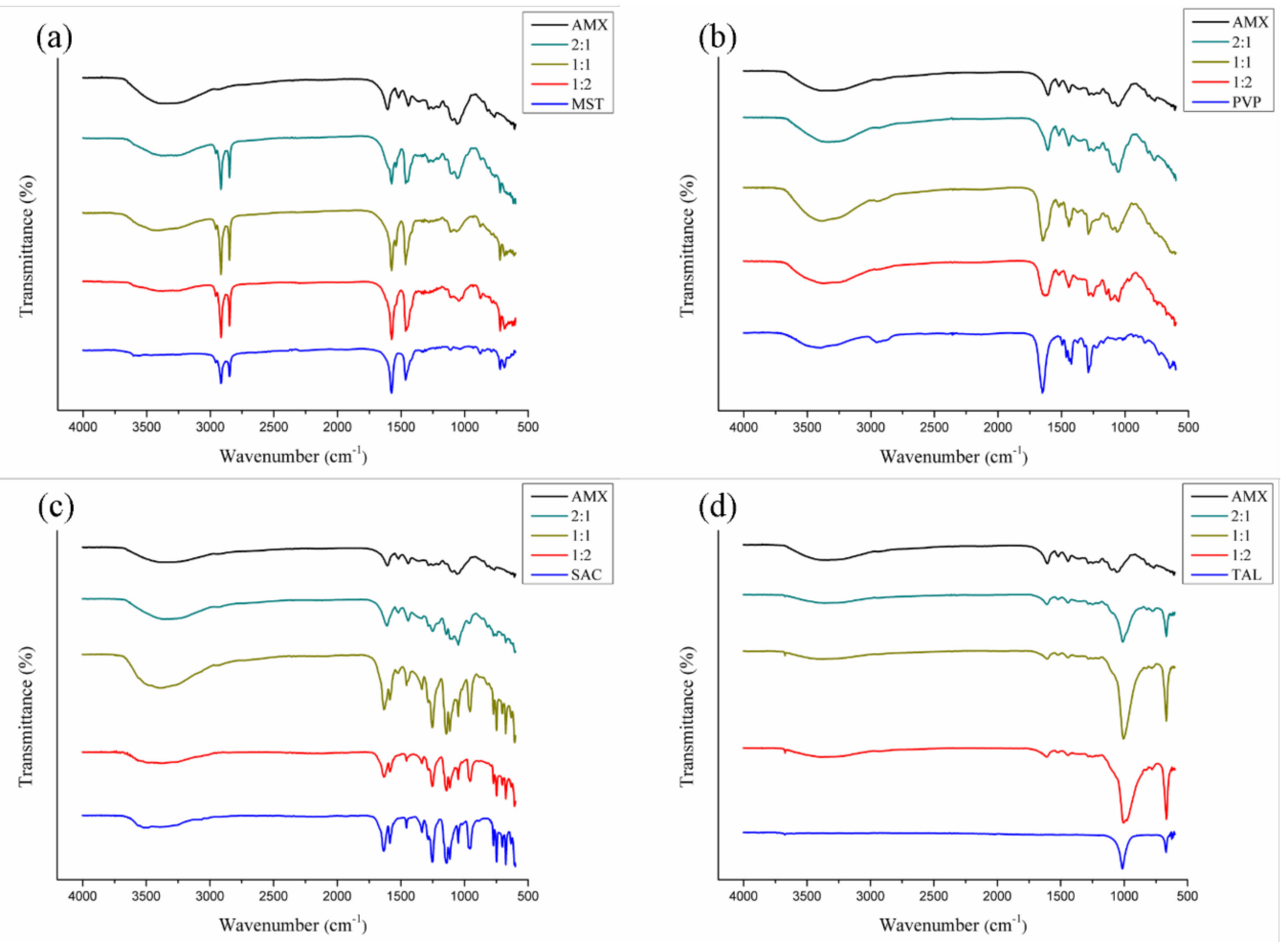

Figure 7. FTIR spectra for binary mixtures of AMX and pharmaceutical excipients: magnesium stearate (a), polyvinylpyrrolidone k-30 (b), sodium saccharin (c), and talc (d).

It is important to note that for the AMX-talc mixtures, the peak intensity of the extract significantly changed, as observed for the AMX-colloidal silicon dioxide mixtures. Once again, this phenomenon can be attributed to the siloxane groups in the pharmaceutical excipient, the presence of which causes an intense absorption at $1080 \mathrm{~cm}^{-1}$, thus promoting attenuation of the other spectral bands [50].

Therefore, the evaluation of the binary AMX-pharmaceutical excipient mixtures by FTIR made it possible to determine that all the excipients studied did not show evidence of chemical incompatibility with the AMX plant extract.

\subsection{Mucoadhesive Tablet Development}

Based on the results obtained in the compatibility studies with DTA and FTIR, the pharmaceutical excipients HPMC, MAN, LAC, MST, and PVP were chosen for the formulation. Different formulations were proposed, fixing the concentrations of MAN, MST, PVP, and AMX and varying the proportions of HPMC and LAC, according to the manual of pharmaceutical inputs [29].

However, unsatisfactory flow was observed when LAC concentrations were added and increased. Therefore, LAC was removed, since the diluent function was already exerted by MAN. The AMX concentration was determined based on a microbiological potency study carried out by our research group. Table 2 shows the composition of the final formulations.

Table 2. Final formulation of the mucoadhesive tablets.

\begin{tabular}{ccc}
\hline Excipient & Concentration (\%) & Class \\
\hline HPMC & 48.97 & Adhesive \\
MAN & 10.00 & Diluent/sweetener \\
MST & 2.00 & Lubricant \\
PVP & 2.00 & Desintegrator \\
AMX & 37.03 & PAPI \\
\hline
\end{tabular}


The final formulation showed an angle of repose between $31^{\circ}$ and $35^{\circ}$, characterized as a good flow. However, the Carr Index (CI) and Hausner's Factor (HF) were classified as very poor flow (CI between 32-37\%, HF between 1.46-1.59). Thus, it was necessary to granulate the powder using an ethanolic solution $(70 \%(v / v)$ at $5 \%$ PVP).

Table 3 shows the characterization data of flow to granulation formulation. The results reveal adequate flow, angle of repose $<30^{\circ}, \mathrm{CI} 12 \%$, and HF 1.13, therefore exhibiting suitability for direct compression [31].

Table 3. Flow characterization data.

\begin{tabular}{ccc}
\hline Parameters & Formulation & Granulate \\
\hline Gross density $\left(\mathrm{g} \cdot \mathrm{mL}^{-1}\right)$ & 0.526 & 0.550 \\
Density of compaction $\left(\mathrm{g} \cdot \mathrm{mL}^{-1}\right)$ & 0.769 & 0.625 \\
Hausner factor & 1.460 & 1.13 \\
Carr index $(\%)$ & 31.60 & 12.0 \\
Index of densification $(\mathrm{mL})$ & 2.00 & 1.0 \\
Angle of repose $\left(^{\circ}\right)$ & 33.00 & 0.15 \\
Flow time $(\mathrm{s})$ & 4.57 & 3.12 \\
\hline
\end{tabular}

\subsection{Mucoadhesion}

Texture Profile Analysis (TPA) is a technique that allows the determination of the mucoadhesive strength (negative area of the force-time curve per unit time required to detach the tablet from the substrate during the first compression cycle) between the tablet and the mucin disk or pig buccal mucosa. The values of a commercial formulation adhesion call (Triancinolone orabase) were used to verify if the mucoadhesive tablet had suitable interactive properties [51].

Figure 8 shows the work of mucoadhesion values (Wad) for the mucoadhesive tablet and the commercial cream formulation.

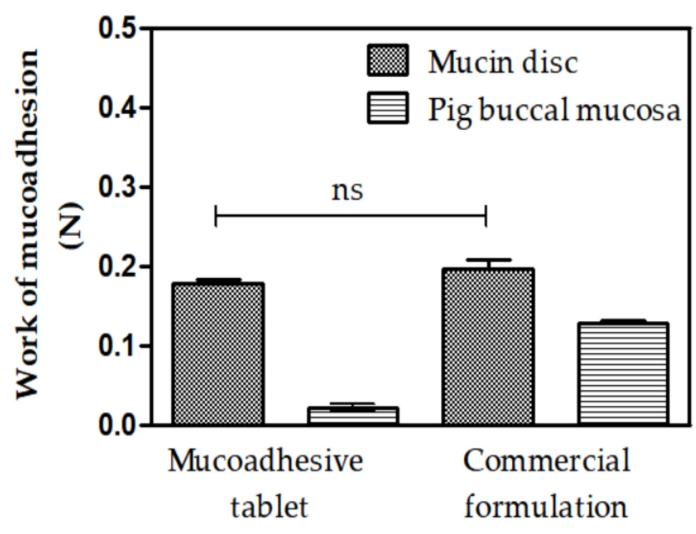

Figure 8. Work of mucoadhesion values for mucoadhesive tablet and commercial mucoadhesive formulations when in contact with mucin discs and pig buccal mucosa. The statistical significance was analyzed using variance analysis via Anova One Way; $p \leq 0.05$. n.s.: no significant difference. Results are expressed as mean $\pm \mathrm{SD}$ for $n=5$.

When the value of the mucoadhesion between the tablet $(0.177 \pm 0.011 \mathrm{~N})$ and the adherent commercial formulation $(0.1972 \pm 0.023 \mathrm{~N})$ using a mucin disk is compared, the value of the work of mucoadhesion displays no statistical difference. Furthermore, we can verify that both materials analyzed in pig buccal mucosa presented values statistically lower than those presented with the mucin discs. However, when comparing the mucoadhesive values the between tablet $(0.022 \pm 0.008 \mathrm{~N})$ and commercial formulation $(0.128 \pm 0.05 \mathrm{~N})$, the tablet has statistically lower adhesion than the commercial formulation. Bespite this, all values 55 obtained in this test have higher work of mucoadhesion than values obtained in other studies dealing with mucoadhesive systems that use the same methodology, supporting the proposal of using these materials as mucoadhesive systems [52-54]. Perioli et al. (2008) 
demonstrated that an increase of the compression force on tablet increases the mucoadhesion values and tablets with the lowest force $(0.57 \mathrm{~N})$ are better than tablets with values above $1.20 \mathrm{~N}$ because they cause pain during in vivo application [55].

The obtained results are due to the chemical structure of polymers used in the tablet. This includes a sufficient amount of chemical groups capable of forming hydrogen bonds $(-\mathrm{OH},-\mathrm{C}=\mathrm{O}$ and $-\mathrm{NH} 2)$ with the biological substrate and swelling capacity, which enables mucosal variations to be adjusted and helps interpenetration between chains of the mucus and the polymeric chains of the tablet. One of the most predominant concepts that explains the process of mucoadhesion is chemo-adsorption, a subtype of the adsorption theory. According to chemo-adsorption, adhesive bonding occurs through secondary forces, including hydrogen bonds, hydrophobic bonds, Van Der Walls interactions, and electrostatic forces, established between the atoms of the bioadhesive material and those of the muco-glycoprotein network; despite being considered as weak interactions, all these together produce an intense adhesive force [56-58].

In this way, the structure of the polymer is an important and influential factor in the mechanism of mucoadhesion. HPMC, a nonionic hydrophilic polymer, has mucoadhesive properties due to the hydroxyl groups present in its structure, making it capable of establishing hydrogen bonds with mucus glycoproteins $[59,60]$. Hydroxypropyl methylcellulose is often used to produce sustained release matrix tablets due to its biocompatibility, biodegradability, easy handling, low cost, ease of compaction, and high drug-loading capacity. Moreover, and most importantly, the release of the drug promoted by the hydrophilic matrix of this polymer is little affected by the process variables [61,62].

Mucoadhesion may improve the administration of antifungal drugs by allowing release of the active ingredient in a specific target region affected by infection. By establishing a consistent interaction between the polymer and mucus, the increased contact time between the two surfaces promotes increased drug action in situ, providing a greater therapeutic efficacy [63-65].

In vivo studies indicate that mucoadhesive tablets may achieve an equal or better therapeutic performance compared to conventional formulations in treating oral candidiasis. Comparing the efficacy and safety of miconazole nitrate tablets and itraconazole capsules in patients diagnosed with oral candidiasis, Yan et al. (2016) found a cure rate of $51.18 \%$ for miconazole and $41.76 \%$ for itraconazole. They also observed no significant differences between these drugs regarding the safety profile of the patients [66]. Evaluating mucoadhesive tablets of nystatin in healthy volunteers, Llabot et al. (2009) found that the tablets resided in the mucosa of the patients for 4.5 hours. During this period, the concentration of nystatin in the saliva remained higher than the MIC of the drug, according to the behavior observed in vitro [67].

\section{Conclusions}

The results showed that, as complementary analytical techniques, DTA and FTIR were effective in the PAPI-excipient compatibility study. The results also demonstrated that Hydroxypropyl methylcellulose, Mannitol, Magnesium Stearate, and Polyvinylpyrrolidone K-30 are the most suitable pharmaceutical adjuvants in the formulation. In addition, the use of the Hydroxypropyl methylcellulose polymer resulted in a tablet with mucoadhesion values similar to commercial formulations and better than other mucoadhesive systems in the literature. Mucoadhesion force assays are relevant to pharmaceutical formulations, since higher mucoadhesion values may increase the time of action and absorption of the drug, thus improving the clinical performance of the formulation. In this way, we can conclude that this formulation may be used as a mucoadhesive tablet and that incorporating antimicrobial X. americana is promising for the treatment of oral infections. The next stage of this work will be to perform in vitro and in vivo experiments in order to prove the efficacy of this new therapeutic approach.

Author Contributions: L.A., M.S., F.N., J.A., W.S., A.R., and M.C. performed the Thermal, Compatibility, FTIR, mucoadesive tablet development, and mucoadhesive studies. J.A.O.J., G.V. and A.C.M. supervised the authors and analyzed all data. All authors assisted in drafting the paper. 
Funding: This study was financed in part by the Coordenação de Aperfeiçoamento de Pessoal de Nível Superior-Brasil (CAPES)-Finance Code 001.

Conflicts of Interest: The authors declare no conflict of interest.

\section{Appendix A}

Table A1. Functional categories of the pharmaceutical excipients used in the compatibility study.

\begin{tabular}{cc}
\hline Excipient/Abbreviation & Functional Category \\
\hline Aspartame (ASP) & Sweetening agent \\
Sodium saccharin (SAC) & Sweetening agent \\
Fructose (FRU) & Sweetening agent \\
Carbopol (CBP) & Mucoadhesive agent \\
Sodium carboxymethylcellulose (CMC) & Mucoadhesive agent \\
Hydroxyethylcellulose (HEC) & Mucoadhesive agent \\
Hydroxypropylmethylcellulose (HPMC) & Mucoadhesive agent \\
Colloidal silicon dioxide (CSD) & Disintegrant \\
Polyvinylpyrrolidone K-30 (PVP)* & Disintegrant \\
Magnesium stearate (MST) & Lubricant \\
Talc (TAL) & Lubricant \\
Mannitol (MAN) & Sweetening agent/diluent \\
Lactose monohydrate (LAC) & Diluent \\
\hline${ }^{*}$ K-value is a viscosity index related to polymer molecular weight [30].
\end{tabular}

Table A2. DTA data of AMX, excipients, and their binary mixtures at 1:1, 1:2, and 2:1 proportions (AMX: excipient).

\begin{tabular}{|c|c|c|c|c|}
\hline Sample & Event & Start-End $\left({ }^{\circ} \mathrm{C}\right)$ & Peak $\left({ }^{\circ} \mathrm{C}\right)$ & $\Delta H\left(\mathrm{~J} \cdot \mathrm{g}^{-1}\right)$ \\
\hline AMX & First & $66.41-126.28$ & 98.67 & -283.69 \\
\hline \multirow{4}{*}{ ASP } & First & $59.72-91.16$ & 80.23 & -35.43 \\
\hline & Second & 178.70-196.78 & 188.87 & -229.97 \\
\hline & Third & $243.79-255.77$ & 249.17 & -183.82 \\
\hline & Fourth & 303.23-347.95 & 325.47 & -281.75 \\
\hline \multirow{4}{*}{ AMX + ASP (1:1) } & First & 55.18-121.32 & 89.03 & -148.52 \\
\hline & Second & $170.02-193.65$ & 183.90 & -123.74 \\
\hline & Third & $222.86-244.21$ & 235.55 & -64.54 \\
\hline & Fourth & $309.01-337.42$ & 322.89 & -14.97 \\
\hline \multirow{5}{*}{ AMX + ASP (1:2) } & First & $53.71-118.83$ & 98.93 & -138.94 \\
\hline & Second & $175.18-193.76$ & 184.97 & -164.40 \\
\hline & Third & $226.99-244.48$ & 237.58 & -87.29 \\
\hline & Fourth & $283.28-304.42$ & 283.53 & -6.79 \\
\hline & Fifth & $308.47-332.22$ & 329.86 & -13.74 \\
\hline \multirow{3}{*}{$\operatorname{AMX}+\operatorname{ASP}(2: 1)$} & First & 50.39-130.82 & 98.62 & -193.24 \\
\hline & Second & 169.74-193.95 & 184.25 & -85.90 \\
\hline & Third & 217.74-241.31 & 234.78 & -25.09 \\
\hline \multirow{4}{*}{$\mathrm{CBP}$} & First & 56.25-113.69 & 86.63 & -185.54 \\
\hline & Second & 181.79-246.38 & 213.91 & -182.44 \\
\hline & Third & $255.62-293.73$ & 272.20 & -95.02 \\
\hline & Fourth & 351.44-368.78 & 362.72 & 14.49 \\
\hline \multirow{2}{*}{$\mathrm{AMX}+\mathrm{CBP}(1: 1)$} & First & $83.02-122.89$ & 104.39 & -70.91 \\
\hline & Second & 303.89-383.38 & 336.16 & -100.08 \\
\hline \multirow{4}{*}{$\mathrm{AMX}+\mathrm{CBP}(1: 2)$} & First & $56.25-113.69$ & 86.63 & -185.54 \\
\hline & Second & $181.79-246.38$ & 213.91 & -182.44 \\
\hline & Third & $255.62-293.73$ & 272.20 & -95.02 \\
\hline & Fourth & 351.44-368.78 & 362.72 & 14.49 \\
\hline $\mathrm{AMX}+\mathrm{CBP}(2: 1)$ & First & $58.93-134.65$ & 106.95 & -195.85 \\
\hline
\end{tabular}


Table A2. Cont.

\begin{tabular}{|c|c|c|c|c|}
\hline Sample & Event & Start-End $\left({ }^{\circ} \mathrm{C}\right)$ & Peak $\left({ }^{\circ} \mathrm{C}\right)$ & $\Delta H\left(\mathrm{~J} \cdot \mathrm{g}^{-1}\right)$ \\
\hline \multirow{3}{*}{$\mathrm{CMC}$} & First & $71.60-126.66$ & 97.97 & -397.78 \\
\hline & Second & $286.00-301.70$ & 290.81 & 133.76 \\
\hline & Third & 312.77-319.61 & 317.74 & 7.90 \\
\hline \multirow{2}{*}{$\mathrm{AMX}+\mathrm{CMC}(1: 1)$} & First & $83.19-128.16$ & 100.75 & -177.71 \\
\hline & Second & 277.55-318.74 & 295.42 & 198.44 \\
\hline \multirow{2}{*}{$\mathrm{AMX}+\mathrm{CMC}(1: 2)$} & First & $75.51-119.36$ & 92.61 & -152.56 \\
\hline & Second & $275.67-316.37$ & 295.63 & 179.56 \\
\hline \multirow{2}{*}{$\mathrm{AMX}+\mathrm{CMC}(2: 1)$} & First & $52.53-128.94$ & 91.95 & -239.41 \\
\hline & Second & 278.07-320.79 & 297.34 & 114.52 \\
\hline CSD & First & $27.62-48.97$ & 35.59 & 21.10 \\
\hline $\mathrm{AMX}+\mathrm{CSD}(1: 1)$ & First & $80.02-107.25$ & 105.60 & -9.19 \\
\hline $\mathrm{AMX}+\mathrm{CSD}(1: 2)$ & First & $55.12-124.84$ & 97.85 & -129.91 \\
\hline $\mathrm{AMX}+\mathrm{CSD}(2: 1)$ & First & $54.21-134.64$ & 100.47 & -181.98 \\
\hline \multirow{3}{*}{ FRU } & First & $87.79-121.41$ & 107.92 & -47.51 \\
\hline & Second & $190.63-210.33$ & 210.13 & 28.19 \\
\hline & Third & $254.48-307.24$ & 279.24 & 309.91 \\
\hline \multirow{3}{*}{ AMX + FRU (1:1) } & First & 118.69-134.69 & 126.09 & -76.91 \\
\hline & Second & 191.94-203.81 & 195.05 & 6.15 \\
\hline & Third & 220.61-235.04 & 222.28 & 13.5 \\
\hline \multirow{3}{*}{ AMX + FRU (1:2) } & First & $90.91-108.74$ & 101.92 & -12.26 \\
\hline & Second & $141.26-164.2$ & 149.76 & 30.95 \\
\hline & Third & $218.17-248.33$ & 237.24 & 136.48 \\
\hline AMX + FRU (2:1) & First & 115.32-138.45 & 121.37 & -294.63 \\
\hline \multirow{3}{*}{ HEC } & First & 59.73-101.83 & 77.73 & -113.76 \\
\hline & Second & $325.83-355.15$ & 343.28 & 237.51 \\
\hline & Third & $359.21-368.49$ & 364.60 & 10.15 \\
\hline \multirow{2}{*}{ AMX + HEC (1:1) } & First & $56.25-128.83$ & 98.58 & -313.54 \\
\hline & Second & $320.82-353.96$ & 344.65 & 26.04 \\
\hline \multirow{2}{*}{ AMX + HEC (1:2) } & First & $59.67-134.47$ & 104.51 & -345.83 \\
\hline & Second & $322.98-369.57$ & 346.98 & 181.95 \\
\hline \multirow{2}{*}{ AMX + HEC (2:1) } & First & $45.45-119.58$ & 91.22 & -281.17 \\
\hline & Second & 376.04-396.15 & 383.22 & 17.62 \\
\hline \multirow{2}{*}{ HPMC } & First & $61.68-112.83$ & 91.18 & -138.66 \\
\hline & Second & $337.66-373.63$ & 356.09 & -89.52 \\
\hline \multirow{2}{*}{ AMX + HPMC (1:1) } & First & 64.97-117.03 & 93.44 & -11.91 \\
\hline & Second & 285.24-334.35 & 316.21 & -46.32 \\
\hline \multirow{3}{*}{ AMX + HPMC (1:2) } & First & $61.99-112.82$ & 89.43 & -103.01 \\
\hline & Second & $336.40-349.92$ & 341.99 & -14.46 \\
\hline & Third & $382.45-428.34$ & 374.75 & -12.19 \\
\hline \multirow{2}{*}{ AMX + HPMC (2:1) } & First & $92.12-125.29$ & 101.68 & -86.69 \\
\hline & Second & $338.29-368.38$ & 344.15 & 9.27 \\
\hline \multirow{4}{*}{ LAC } & First & $142.89-156.77$ & 146.52 & -183.12 \\
\hline & Second & $214.47-226.32$ & 219.34 & -226.34 \\
\hline & Third & 237.71-246.58 & 241.72 & -3.62 \\
\hline & Fourth & $284.67-323.80$ & 304.85 & -137.36 \\
\hline \multirow{3}{*}{ AMX + LAC (1:1) } & First & $84.56-110.61$ & 99.90 & -2.19 \\
\hline & Second & 141.61-156.27 & 147.46 & -25.28 \\
\hline & Third & 199.51-211.00 & 207.32 & -45.78 \\
\hline \multirow{2}{*}{$\mathrm{AMX}+\mathrm{LAC}(1: 2)$} & First & $142.76-157.07$ & 146.90 & -216.02 \\
\hline & Second & 204.29-216.80 & 211.31 & -463.07 \\
\hline \multirow{3}{*}{ AMX + LAC (2:1) } & First & $82.80-126.49$ & 97.99 & -15.28 \\
\hline & Second & 139.37-155.15 & 147.19 & -59.60 \\
\hline & Third & $202.50-218.73$ & 210.83 & -72.55 \\
\hline
\end{tabular}


Table A2. Cont.

\begin{tabular}{|c|c|c|c|c|}
\hline Sample & Event & Start-End $\left({ }^{\circ} \mathrm{C}\right)$ & Peak $\left({ }^{\circ} \mathrm{C}\right)$ & $\Delta H\left(\mathrm{~J} \cdot \mathrm{g}^{-1}\right)$ \\
\hline \multirow{2}{*}{ MAN } & First & $165.99-177.62$ & 169.89 & -450.53 \\
\hline & Second & 280.49-353.91 & 321.83 & -812.74 \\
\hline AMX + MAN (1:1) & First & $157.97-171.08$ & 163.10 & -50.80 \\
\hline \multirow{2}{*}{ AMX + MAN (1:2) } & First & 157.32-175.31 & 165.63 & -503.47 \\
\hline & Second & $237.23-329.28$ & 304.15 & -585.71 \\
\hline \multirow{3}{*}{ AMX + MAN (2:1) } & First & $85.87-125.00$ & 112.56 & -22.99 \\
\hline & Second & $154.30-171.26$ & 162.94 & -130.24 \\
\hline & Third & $283.03-340.83$ & 325.73 & -47.41 \\
\hline \multirow{4}{*}{ MST } & First & $45.31-54.35$ & 50.91 & -7.99 \\
\hline & Second & $119.80-137.59$ & 129.00 & -255.25 \\
\hline & Third & $154.00-159.72$ & 156.07 & -4.08 \\
\hline & Fourth & $276.41-343.01$ & 319.75 & -379.49 \\
\hline AMX + MST (1:1) & First & $123.76-138.22$ & 127.43 & -71.44 \\
\hline \multirow{2}{*}{ AMX + MST (1:2) } & First & $112.93-134.13$ & 123.68 & -126.77 \\
\hline & Second & $341.03-401.02$ & 366.74 & -204.32 \\
\hline AMX + MST (2:1) & First & $120.27-135.90$ & 126.36 & -51.45 \\
\hline PVP K-30 & First & $53.58-125.06$ & 97.61 & -515.18 \\
\hline AMX + PVP (1:1) & First & $54.43-116.18$ & 87.01 & -147.70 \\
\hline AMX + PVP (1:2) & First & $89.84-141.02$ & 116.75 & -202.44 \\
\hline $\mathrm{AMX}+\mathrm{PVP}(2: 1)$ & First & $51.22-126.61$ & 92.02 & -273.58 \\
\hline \multirow{4}{*}{ SAC } & First & $42.16-67.71$ & 60.76 & -139.27 \\
\hline & Second & $114.9-136.39$ & 120.25 & -281.00 \\
\hline & Third & $126.89-131.67$ & 129.85 & -5.52 \\
\hline & Fourth & $361.66-370.92$ & 365.15 & -210.17 \\
\hline \multirow{3}{*}{ AMX + SAC (1:1) } & First & $42.16-67.71$ & 60.76 & -139.27 \\
\hline & Second & $114.9-136.39$ & 120.25 & -281.00 \\
\hline & Third & $361.66-370.92$ & 365.15 & -26.91 \\
\hline \multirow{4}{*}{ AMX + SAC (1:2) } & First & $64.6-74.86$ & 70.58 & -10.73 \\
\hline & Second & $115.34-135.1$ & 126.04 & -40.79 \\
\hline & Third & $140.88-152.57$ & 145.45 & -55.66 \\
\hline & Fourth & $349.31-364.54$ & 357.99 & -65.39 \\
\hline \multirow{3}{*}{$\mathrm{AMX}+\mathrm{SAC}(2: 1)$} & First & $66.61-83.47$ & 73.97 & -29.27 \\
\hline & Second & $128.34-147.75$ & 137.68 & -26.45 \\
\hline & Third & $348.6-365.37$ & 356.49 & -18.02 \\
\hline TAL & First & $38.13-51.22$ & 44.70 & -11.76 \\
\hline AMX + TAL (1:1) & First & $74.88-111.55$ & 99.76 & -27.33 \\
\hline AMX + TAL (1:2) & - & - & - & - \\
\hline AMX + TAL (2:1) & First & $65.31-129.85$ & 106.16 & -113.68 \\
\hline
\end{tabular}

\section{References}

1. Kassem, A.A.; Mohsen, A.M.; Ahmed, R.S.; Essam, T.M. Self-nanoemulsifying drug delivery system (SNEDDS) with enhanced solubilization of nystatin for treatment of oral candidiasis: Design, optimization, in vitro and in vivo evaluation. J. Mol. Liq. 2016, 218, 219-232. [CrossRef]

2. Muadcheingka, T.; Tantivitayakul, P. Distribution of Candida albicans and non-albicans Candida species in oral candidiasis patients: Correlation between cell surface hydrophobicity and biofilm forming activities. Arch. Oral Biol. 2015, 60, 894-901. [CrossRef] [PubMed]

3. Pilmis, B.; Jullien, V.; Sobel, J.; Lecuit, M.; Lortholary, O.; Charlier, C. Antifungal drugs during pregnancy: An updated review. J. Antimicrob. Chemother. 2015, 70, 14-22. [CrossRef] [PubMed]

4. $\quad$ Lins, R.; Vasconcelos, F.H.P.; Leite, R.B.; Coelho-Soares, R.S.; Barbosa, D.N. Avaliação clínica de bochechos com extratos de aroeira (Schinus terebinthifolius) e camomila (Matricaria recutita L.) sobre a placa bacteriana e a gengivite. Rev. Bras. Plant. Med. 2013, 15, 112-120. [CrossRef] 
5. Chanda, W.; Joseph, T.P.; Wang, W.; Padhiar, A.A.; Zhong, M. The potential management of oral candidiasis using anti-biofilm therapies. Med. Hypotheses 2017, 106, 15-18. [CrossRef] [PubMed]

6. Pantoja, P.S.; Assreuy, A.M.S.; Silva, R.O.; Damasceno, S.R.B.; Mendonça, V.A.; Mendes, T.S.; Morais, J.A.V.; Almeida, S.L.; Teixeira, A.E.E.A.; Souza, M.H.L.P.; et al. The polysaccharide-rich tea of Ximenia americana barks prevents indomethacin-induced gastrointestinal damage via neutrophil inhibition. J. Ethnopharmacol. 2018, 224, 195-201. [CrossRef] [PubMed]

7. Sobeh, M.; Mahmoud, M.F.; Abdelfattah, M.A.O.; El-Beshbishy, H.A.; El-Shazly, A.M.; Wink, M. Hepatoprotective and hypoglycemic effects of a tannin rich extract from Ximenia americana var. caffra root. Phytomedicine 2017, 33, 36-42. [CrossRef] [PubMed]

8. Almeida, M.L.B.; Freitas, W.E.S.; de Morais, P.L.D.; Sarmento, J.D.A.; Alves, R.E. Bioactive compounds and antioxidant potential fruit of Ximenia americana L. Food chem. 2016, 192, 1078-1082.

9. Uchôa, V.T.; Sousa, C.M.M.; Carvalho, A.A.; Sant'Ana, A.E.G.; Chaves, M.H. Free radical scavenging ability of Ximenia americana L. stem bark and leaf extracts. J. Appl. Pharm. Sci. 2016, 6, 091-096.

10. Soro, T.Y.; Zahoui, O.S.; Néné-bi, A.S.; Traoré, F. Antipyretic activity of the fractions of the aqueous extract of Ximenia americana (Linnaeus)(Olacaceae). Int. J. Pharmacol. Toxicol. 2015, 5, 104-108.

11. Ribeiro, D.A.; Macêdo, D.G.; Oliveira, L.G.S.; Saraiva, M.E.; Oliveira, S.F.; Souza, M.M.A.; Menezes, I.R.A. Potencial terapêutico e uso de plantas medicinais em uma área de Caatinga no estado do Ceará, nordeste do Brasil. Rev. Bras. Plant. Med. 2014, 16, 912-930. [CrossRef]

12. Siddaiah, M.; Veera, K.J.; Rao, P.M.; Reddy, K.Y.; Chetty, C.M. Screening of Ximenia americana L. for it's anti-iflammatory activity. J. Res. Educ. Indian Med. 2012, 18, 51-54.

13. Okhale, S.E.; Nnachor, A.C.; Bassey, U.E. Evaluation of HPLC-DAD and antiproliferative characteristics of the leaf infusion of Ximenia americana Linn. MicroMedicine 2017, 5, 45-52.

14. Santana, C.P.; Medeiros, F.D.; Correia, L.P.; Diniz, P.H.G.; Véras, G.; Medeiros, A.C.D. Dissolution and uniformity of contente of tablets developed with extract of Ximenina americana L. PLoS ONE 2018, 13. [CrossRef]

15. Kabran, G.R.M.; Mamyrbekova-Bekro, J.A.; Pirat, J.L.; Lecouvey, M.; Sainte-Cathérine, O.; Sommerer, N.; Verbaere, A.; Meudec, E.; Békro, Y.A. UPLC-MS quantification and anticancer potential of Ximenia americana hydro-acetonic crude extract leaves. Der Chem. Sin. 2017, 8, 70-74.

16. Santana, C.P.; Fernandes, F.H.; Brandão, D.O.; Silva, P.C.D.; Correia, L.P.; Nóbrega, F.P.; medeiros, F.D.; Diniz, P.H.G.D.; Véras, G.; Medeiros, A.C.D. Compatibility study of dry extract of Ximenia americana L. and pharmaceutical excipients used in solid state. J. Therm. Anal. Calorim. 2018, 133, 603-617. [CrossRef]

17. Sheetar, A.K.; Kotresha, K.; Kaliwal, B.B.; Vedamurthy, A.B. Evaluation of in vitro antioxidant and anti-inflammatory activities of Ximenia americana extracts. Asian Pac. J. Trop. Dis. 2015, 5, 918-923. [CrossRef]

18. Sheetar, A.K.; Sateesh, M.K.; Kaliwal, B.B.; Vedamurthy, A.B. In vitro antidiabetic activities and GC-MS phytochemical analysis of Ximenia americana extracts. S. Afr. J. Bot. 2017, 111, 202-211.

19. Sá, L.L.F.; Nogueira, N.C.; da Silva Filho, E.C.; Figueiras, A.; Veiga, F.; Nunes, L.C.C.; Soares-Sobrinho, J.L. Design of buccal mucoadhesive tablets: Understanding and development. J. Appl. Pharm. Sci. 2018, 8, 150-163.

20. Fitaihi, R.A.; Aleanizy, F.S.; Elsamaligy, S.; Mahmoud, H.A.; Bayomi, M.A. Role of chitosan on controlling the characteristics and antifungal activity of bioadhesive fluconazole vaginal tablets. Saudi Pharm. J. 2018, 26, 151-161.

21. Reddy, P.D.; Balanjineyulu, R.; Swarnalatha, D.; Badarinath, A.V.; Gopinath, C. Design, development and in vitro characterization of felodipine mucoadhesive buccal tablets. J. Pharm. Res. 2015, 9, 170-176.

22. Khutoryanskiy, V.V. Advances in mucoadhesion and mucoadhesive polymers. Macromol. Biosci. 2011, 11, 748-764. [CrossRef] [PubMed]

23. Fabiano, A.; Piras, A.M.; Uccello-Barretta, G.; Balzano, F.; Cesari, A.; Testai, L.; Citi, V.; Zambito, Y. Impact of mucoadhesive polymeric nanoparticulate systems on oral bioavailability of a macromolecular model drug. Eur. J. Pharm. Biopharm. 2018, 130, 281-289. [CrossRef] [PubMed]

24. Sahatsapan, N.; Rojanarata, T.; Ngawhirunpat, T.; Opanasopit, P.; Tonglairoum, P. 6-Maleimidohexanoic acid-grafted chitosan: A new generation mucoadhesive polymer. Carbohydr. Polym. 2018, 202, 258-264. [PubMed]

25. Wasnik, M.N.; Godse, R.D.; Nair, H.A. Development and evaluation of buccoadhesive tablet for selegiline hydrochloride based on thiolated polycarbophil. Drug Dev. Ind. Pharm. 2014, 40, 632-638. [PubMed] 
26. Da Costa, R.S.; Negrão, C.A.B.; Camelo, S.R.P.; Ribeiro-Costa, R.M.; Barbosa, W.L.R.; da Costa, C.E.F.; Júnior, J.O.C.S. Investigation of thermal behavior of Heliotropium indicum L. lyophilized extract by TG and DSC. J. Therm. Anal. Calorim. 2013, 111, 1959-1964. [CrossRef]

27. Liltorp, K.; Larsen, T.G.; Willumsen, B.; Holm, R. Solid state compatibility studies with tablet excipients using non thermal methods. J. Pharm. Biomed. Anal. 2011, 55, 424-428. [CrossRef]

28. Clinical and Laboratory Standards Institute (CLSI). Reference Method for Broth Dilution Antifungal Susceptibility Testing of Yeasts: Approved Standard, 2nd ed.; Clinical and Laboratory Standards Institute (CLSI): Wayne, NJ, USA, 2002; Volume 22, 30p.

29. Rowe, R.C.; Sheskey, P.J.; Quinn, M.C. Handbook of Pharmaceutical Excipients, 6th ed.; Pharmaceutical Press: Washington, DC, USA, 2009.

30. Gupta, R.; Sharma, P.; Garg, A.; Soni, A.; Sahu, A.; Rai, S.; Rai, S.; Shukla, A. Formulation and evaluation of herbal effervescent granules incorporated with Calliandra haematocephala leaves extract. Indo Am. J. Pharm. Res. 2013, 3, 4366-4371.

31. Lago, V.V.; Pereira, R.N.; Bertol, C.D. Propriedades micromeríticas e análise físico-química de matérias-primas de alopurinol. Rev. Ciênc. Farm. Básica Apl. 2012, 33, 385-393.

32. Bernatoniete, J.; Petkeviciute, Z.; Kalveniene, Z.; Masteikova, R.; Draksiene, G.; Muselik, J.; Bernatoniene, R.; Lazauskas, R.; Savickas, A. The investigation of phenolic compounds and technological properties of Leonurus, Crataegus and Ginkgo extracts. J. Med. Plants Res. 2010, 4, 925-931.

33. Oshiro Junior, J.A.; Carvalho, F.C.; Soares, C.P.; Chorilli, M.; Chiavacci, L.A. Development of Cutaneous Bioadhesive Ureasil-Polyether Hybrid Films. Int. J. Polym. Sci. 2015. [CrossRef]

34. Oshiro Junior, J.A.; Nasser, N.J.; Chiari-Andréo, B.G.; Cuberes, T.; Chiavacci, L.A. Study of triamcinolone release and mucoadhesive properties of macroporous hybrid films for oral disease treatment. Biomed. Phys. Eng. Express 2018, 4, 035009.

35. Omer, M.E.F.A.; Elnima, E.I. Antimicrobial activity of Ximenia americana. Fitoterapia 2003, 74, $122-126$.

36. Maikai, V.A. Antimicrobial properties of stem bark extracts of Ximenia americana. J. Agric. Sci. 2009, 1, 30-34.

37. Runyoro, D.K.B.; Ngassapa, O.D.; Matee, M.I.N.; Joseph, C.C.; Moshi, M.J. Medicinal plants used by Tanzanian traditional healers in the management of Candida infections. J. Ethnopharmacol. 2006, 106, 158-165. [CrossRef]

38. Traoré, M.S.; Baldé, M.A.; Camara, A.; Baldé, E.S.; Diané, S.; Diallo, M.S.T.; Keita, A.; Cos, P.; Maes, L.; Pieters, L.; et al. The malaria co-infection challenge: An investigation into the antimicrobial activity of selected Guinean medicinal plants. J. Ethnopharmacol. 2015, 174, 576-581. [CrossRef] [PubMed]

39. Maroyi, A. Ximenia caffra Sond. (Ximeniaceae) in sub-Saharan Africa: A synthesis and review of its medicinal potential. J. Ethnopharmacol. 2016, 184, 81-100. [PubMed]

40. Van Vuuren, S.; Holl, D. Antimicrobial natural product research: A review from a South African perspective for the years 2009-2016. J. Ethnopharmacol. 2017, 208, 236-252.

41. Lagrouh, F.; Dakka, N.; Bakri, Y. The antifungal activity of Moroccan plants and the mechanism of action of secondary metabolites from plants. J. Mycol. Med. 2017, 27, 303-311.

42. Zaynab, M.; Fatima, M.; Abbas, S.; Sharif, Y.; Umair, M.; Zafar, M.H.; Bahadar, K. Role of secondary metabolites in plant defense against pathogens. Microb. Pathog. 2018, 124, 198-202. [CrossRef]

43. Chadha, R.; Bhandari, S. Drug-excipient compatibility screening: Role of thermoanalytical and spectroscopic techniques. J. Pharm. Biomed. Anal. 2014, 87, 82-97. [CrossRef] [PubMed]

44. Fernandes, H.A.; Santana, C.S.; Silva, P.C.D.; Simões, M.O.S.; Kaneko, T.M.; Medeiros, A.C.D. Development of a sunscreen by thermal compatibility study using Schinopsis brasiliensis Engler extract as preservative. J. Therm. Anal. Calorim. 2018, 131, 753-763. [CrossRef]

45. Neil, M.J. (Ed.) The Merck Index, 15th ed.; Merck \& Co., Inc.: Whitehouse Station, NJ, USA, 2013.

46. Tita, B.; Fulias, A.; Bangur, G.; Marian, E.; Tita, D. Compatibility study between ketoprofen and pharmaceutical excipients used in solid dosage forms. J. Pharm. Biomed. Anal. 2011, 56, 221-227. [PubMed]

47. Lawrence, J.F. Saccharin. In Encyclopedia of Food Sciences and Nutrition, 2nd ed.; Caballero, B., Ed.; Academic Press: New York, NY, USA, 2003; pp. 5033-5035.

48. Ledeti, I.; Bolintineanu, S.; VLASE, G.; Circioban, D.; Ledeti, A.; Vlase, T.; Suta, L.; Caunii, A.; Murariu, M. Compatibility study between antiparkinsonian drug levodopa and excipients by FTIR spectroscopy, X-ray diffraction and thermal analysis. J. Therm. Anal. Calorim. 2017, 130, 433-441. [CrossRef] 
49. Chaves, L.L.; Rolim, L.A.; Gonçalves, M.L.C.M.; Vieira, A.C.C.; Alves, L.D.S.; Soares, M.F.R.; Soares-Sobrinho, J.L.; Lima, M.C.A.; Rolim-Neto, P.J. Study of stability and drug-excipient compatibility of diethylcarbamazine citrate. J. Therm. Anal. Calorim. 2013, 111, 2179-2186.

50. Pinto, M.F.; Moura, E.A.; Souza, F.S.; Macêdo, R.O. Thermal compatibility studies of nitroimidazoles and excipients. J. Therm. Anal. Calorim. 2010, 102, 323-329.

51. Bento da Silva, P.; Calixto, G.M.F.; Oshiro Júnior, J.A.; Bombardelli, R.L.Á.; Fonseca-Santos, B.; Rodero, C.F.; Chorilli, M. Structural features and the anti-inflammatory effect of green tea extract-loaded liquid crystalline systems intended for skin delivery. Polymers 2017, 9, 30. [CrossRef]

52. Andrews, G.P.; Laverty, T.P.; Jones, D.S. Mucoadhesive polymeric platforms for controlled drug delivery. Eur. J. Pharm. Biopharm. 2009, 71, 505-518.

53. Bruschi, M.L.; Jones, D.S.; Panzeri, H.; Gremião, M.P.; de Freitas, O.; Lara, E.H. Semisolid systems containing propolis for the treatment of periodontal disease: In vitro release kinetics, syringeability, rheological, textural, and mucoadhesive properties. J. Pharm. Sci. 2007, 96, 2074-2089. [CrossRef]

54. Salmazi, R.; Calixto, G.; Bernegossi, J.; Ramos, M.A.S.; Bauab, T.M.; Chorilli, M. A curcumin-loaded liquid crystal precursor mucoadhesive system for the treatment of vaginal candidiasis. Int. J. Nanomed. 2015, $10,4815$.

55. Perioli, L.; Ambrogi, V.; Giovagnoli, S.; Blasi, P.; Mancini, A.; Ricci, M.; Rossi, C. Influence of compression force on the behaviour of mucoadhesive buccal tablets. AAPS PharmSciTech 2008, 9, 274-281. [CrossRef] [PubMed]

56. Guilhotra, R.M.; Ikram, M.; Srivastava, S.; Gilhotra, N. A clinical perspective on mucoadhesive buccal drug delivery systems. J. Biomed. Res. 2014, 28, 81-97.

57. Mansuri, S.; Kesharwani, P.; Jain, K.; Tekade, R.K.; Jain, N.K. Mucoadhesion: A promising approach in drug delivery system. React. Funct. Polym. 2016, 100, 151-172.

58. Partenhauser, A.; Bernkop-Schnuerch, A. Mucoadhesive polymers in the treatment of dry X syndrome. Drug Discov. Today 2016, 21, 1051-1062. [PubMed]

59. Chakraborti, C.K.; Sahoo, S.; Behera, P.K. Role of different biodegradable polymers on the permeability of ciprofloxacin. J. Adv. Pharm. Technol. Res. 2014, 5, 140-146. [CrossRef] [PubMed]

60. Bartkowiak, A.; Rojewska, M.; Hyla, K.; Zembrzuska, J.; Prochaska, K. Surface and swelling properties of mucoadhesive blends and their ability to release fluconazole in a mucin environment. Colloids Surf. B Biointerfaces 2018, 172, 586-593. [CrossRef]

61. Novak, S.D.; Šporar, E.; Baumgartner, S.; Vrečer, F. Characterization of physicochemical properties of hydroxypropyl methylcellulose (HPMC) type 2208 and their influence on prolonged drug release from matrix tablets. J. Pharm. Biomed. Anal. 2012, 66, 136-143.

62. Viridén, A.; Wittgren, B.; Larsson, A. Investigation of critical polymer properties for polymer release and swelling of HPMC matrix tablets. Eur. J. Pharm. Sci. 2009, 36, 297-309. [CrossRef] [PubMed]

63. Pereirinha, P.R.P.; Figueiras, A.R.R. Desenvolvimento de sistemas mucoadesivo para a administração controlada de fármacos. Boletim Inform. Geum 2016, 7, 63-81.

64. Cevher, E.; Açma, A.; Sinani, G.; Aksu, B.; Zloh, M.; Mülazımoğlu, L. Bioadhesive tablets containing cyclodextrin complex of itraconazole for the treatment of vaginal candidiasis. Int. J. Biol. Macromol. 2014, 69, 124-136. [CrossRef]

65. Tonglairoum, P.; Ngawhirunpat, T.; Rojanarata, T.; Panomsuk, S.; Kaomongkolgit, R.; Opanasopit, P. Fabrication of mucoadhesive chitosan coated polyvinylpyrrolidone/ cyclodextrin/clotrimazole sandwich patches for oral candidiasis. Carbohydr. Polym. 2015, 132, 173-179. [PubMed]

66. Yan, Z.; Liu, X.; Liu, Y.; Han, Y.; Lin, M.; Wang, W.; Guan, X.; Zhu, S.; Zhang, H.; Wang, Q.; et al. The efficacy and safety of miconazole nitrate mucoadhesive tablets versus itraconazole capsules in the treatment of oral candidiasis: An open-label, randomized, multicenter trial. PLoS ONE 2016, 11, e0167880. [CrossRef] [PubMed]

67. Llabot, J.M.; Manzo, R.H.; Allemandi, D.A. Novel mucoadhesive extended release tablets for treatment of oral candidosis: "in vivo" evaluation of the biopharmaceutical performance. J. Pharm. Sci. 2009, 98, 1871-1876. [PubMed]

(C) 2019 by the authors. Licensee MDPI, Basel, Switzerland. This article is an open access article distributed under the terms and conditions of the Creative Commons Attribution (CC BY) license (http://creativecommons.org/licenses/by/4.0/). 